\title{
Conceptual model of regional groundwater flow based on hydrogeochemistry (Montérégie Est, Québec, Canada)
}

\author{
Châtelaine Beaudry ${ }^{1}$, René Lefebvre ${ }^{1 \mathrm{C}}$, Christine Rivard $^{2} \&$ Vincent $^{\text {Cloutier }}{ }^{3}$ \\ 1 Centre Eau Terre Environnement, Institut national de la recherche scientifique (INRS), \\ 490 rue de la Couronne, Québec, Québec, Canada G1M 3X3 \\ C Corresponding author: 418-654-2651, rene.lefebvre@ete.inrs.ca \\ 2 Geological Survey of Canada, Natural Resources Canada, Québec, Québec, Canada \\ 3 Institut de recherche en mines et en environnement (IRME), Université du Québec en \\ Abitibi-Témiscamingue (UQAT), Amos, Québec, Canada
}

\section{For the use of the editors}

\section{Paper \#:}

\section{Submitted on:}

\section{Accepted on:}

Application - Research - Commentary - Book Review:

\section{Copyright Held by:}

\section{T2012}

\section{Abstract:}

19 [The groundwater geochemistry of the fractured rock aquifer system in the Montérégie

20 Est region, southern Quebec, Canada, was studied as part of a regional groundwater 21 resources assessment. The $9,218 \mathrm{~km}^{2}$ study area included three major watersheds that

22 were divided into five hydrogeological contexts: Northern St. Lawrence Lowlands,

23 Southern St. Lawrence Lowlands, Appalachian Uplands, Appalachian Piedmont and

24 Monteregian Hills. A large part of this study area was invaded by the Champlain Sea

25 from 13,000 to 11,000 years ago. Study objectives were to identify the mechanisms

26 controlling groundwater composition and to support the understanding of the aquifer

27 hydrodynamics. Groundwater from 206 wells drilled into the rock aquifer was sampled

28 and analyzed for conventional parameters and isotopic analyses were also done on

29 selected samples $\left(\delta^{2} \mathrm{H}, \delta^{18} \mathrm{O}\right.$ and ${ }^{3} \mathrm{H}$ of water; $\delta^{13} \mathrm{C}$ and ${ }^{14} \mathrm{C}$ of dissolved inorganic 
30 carbon). The interpretation of geochemical results was based on a multivariate statistical 31 analysis, which led to the definition of 8 water groups. The study allowed the delineation 32 of a $2,200 \mathrm{~km}^{2}$ zone containing brackish groundwater of marine origin in the north33 western part of the study area. This zone is surrounded by sodic and alkaline groundwater 34 originating from $\mathrm{Na}^{+}-\mathrm{Ca}^{2+}$ ionic exchange. Young groundwater and therefore recharge 35 zones were only encountered in the southern part of the Lowlands, in the northern part of 36 the Piedmont and in the Appalachian Uplands. In the southern part of Lowlands, recharge

37 is presumed to be slow and water composition shows influence of the former presence of 38 the Champlain Sea. Relatively deep groundwater circulation was also inferred to occur 39 from the Appalachian Uplands towards mixing zones mainly located to the west at the 40 Appalachian frontal thrust faults and around Monteregian Hills. The geochemical 41 interpretation provided indications on regional recharge and discharge zones as well as 42 groundwater flow, which could not have been determined otherwise.]

\section{Résumé :}

44 [L'étude hydrogéochimique du système aquifère rocheux fracturé de la Montérégie Est, 45 sud du Québec, Canada, a fait partie d'une évaluation régionale des ressources en eau 46 souterraine. La région d'étude de $9218 \mathrm{~km}^{2}$ couvrait trois bassins versants qui avaient été 47 divisés en cinq contextes hydrogéologiques : les Basses-terres-du-Saint-Laurent nord, les 48 Basses-terres-du-Saint-Laurent sud, le Piémont appalachien, les Hautes-terres des 49 Appalaches, et les Collines montérégiennes. Une partie importante de cette région a été 50 envahie par la Mer de Champlain il y a environ 13000 à 11000 ans. L'étude avait 51 comme objectifs d'identifier les mécanismes contrôlant la composition de l'eau 52 souterraine et de supporter la compréhension de l'hydrodynamique de l'aquifère. L'étude 53 est basée sur les analyses chimiques de 206 échantillons d'eau de puits dans l'aquifère 54 rocheux et d'analyses isotopiques sur une sélection d'échantillons $\left(\delta^{2} \mathrm{H}, \delta^{18} \mathrm{O}\right.$ et ${ }^{3} \mathrm{H}$ de 55 l'eau; $\delta^{13} \mathrm{C}$ et ${ }^{14} \mathrm{C}$ du carbone inorganique dissous). Huit groupes d'eau ont été définis par 56 des méthodes statistiques multivariées. L'étude a permis de circonscrire une zone de 2 $57200 \mathrm{~km}^{2}$ d'eau saumâtre d'origine marine dans le nord-ouest de la région. Cette zone est 58 entourée d'eaux alcalines et sodiques résultant de l'échange ionique $\mathrm{Na}^{+}-\mathrm{Ca}^{2+}$. Des eaux 59 jeunes associées aux zones de recharge sont rencontrées dans le sud des Basses-terres, 
60 dans le nord du Piémont ainsi dans les Hautes-terres appalachiennes. La recharge est

61 présumée lente dans le sud des Basses-terres où la chimie des eaux est influencée par

62 l'ancienne Mer de Champlain. Une circulation relativement profonde d'eau souterraine

63 est présumée se produire à partir des Hautes-terres jusqu'à des zones de mélange situées

64 surtout à l'ouest des chevauchements du front appalachien ainsi qu'autour des

65 montérégiennes. L’interprétation géochimique a donné des indications clés sur les zones

66 de recharge et d'émergence de l'eau souterraine et sur le système d'écoulement régional

67 qui n'auraient pas pu être obtenues autrement.]

68 Keywords: hydrogeochemistry, aquifer system, regional flow, conceptual model, marine invasion

\section{Introduction}

70 [Montérégie Est is a 9,218 $\mathrm{km}^{2}$ region located in southern Quebec, Canada, to the east of 71 Montreal (Figure 1). The fractured rock regional aquifer system was studied between 722009 and 2013 as part of a systematic aquifer characterization program (PACES) 73 launched by the province of Quebec in 2008 (Palmer et al. 2011; MDDELCC 2017). 74 Besides providing the required PACES outputs, the Montérégie Est study aimed to 75 develop an efficient integrated approach not only using conventional hydrogeological 76 techniques and geochemical datasets, but also other information sources, such as 77 geotechnical soundings, borehole geophysics and surface seismic (Lefebvre et al. 2011; 78 Carrier et al. 2013). This approach was adapted from a previously developed 79 methodology for the characterization of heterogeneity in shallow granular aquifers to 80 study the migration of contaminant plumes (Tremblay et al. 2014; Paradis et al. 2014).

81 For the specific groundwater geochemical study reported in this paper, initial available 82 geochemical data were sparse and most data were more than 30 years old. There was thus 83 a need to significantly increase the geochemical dataset to provide a regional 84 groundwater quality assessment and to help understand the groundwater flow system.

85 Following the example of previous regional aquifer studies (Cloutier et al. 2008; 86 Blanchette et al. 2010; Montcoudiol et al. 2015; Pétré et al. 2016; Rey et al. 2017), the 87 perspective of this work was to use the indications provided by groundwater 88 geochemistry and isotopes to develop a better understanding of specific aspects of the 
89 flow system that could not be determined on the basis of its geological context or by

90 physical hydrogeological data. Although the processes leading to the geochemical and

91 isotopic composition of groundwater are identified and graphical evidences of their

92 occurrence are shown, this work is not meant to explain these processes in details.

93 Geochemical evidences are rather used to trace the paths of groundwater flow and

94 identify relationships between different parts of the flow system, from recharge to

95 discharge areas. The specific objectives of the groundwater geochemical study were thus

96 to:

97 - Define groundwater groups and identify their origins, their relations, and the main

98 mechanisms controlling their physical and chemical characteristics;

99 - Use groundwater groups to support the interpretation of groundwater regional 100 circulation patterns and identify recharge and discharge zones.]

\section{Study Area}

102 [The Montérégie Est region is bordered by the St. Lawrence River to the northwest and by 103 the states of Vermont and New York (U.S.A.) to the south (Figure 1). It covers three 104 major watersheds: those of the Richelieu River and Missisquoi Bay, which are sub105 watersheds of the Lake Champlain watershed, and that of the Yamaska River. The 106 territory includes 108 municipalities and $\sim 790,000$ inhabitants. Agriculture is one of the 107 major economic drivers of this region. Five distinct hydrogeological contexts were 108 defined in Montérégie Est based on physiography and bedrock geology: Northern St.

109 Lawrence Lowlands, Southern St. Lawrence Lowlands, Appalachian Uplands, 110 Appalachian Piedmont and Monteregian Hills. Figure 1 shows the physiographic features 111 whereas Figure 2 illustrates subsurface conditions, including bedrock geology and 112 surficial sediments.

113 Figure 1. Montérégie Est location and hydrogeological contexts based on 114 physiography. Map also shows topography, main roads, the Champlain Sea 115 maximum marine transgression limit $(\mathbf{1 3 , 0 0 0}$ to 11,000 years ago $)$ and the trace of 116 the cross-sections shown on the 3D block diagram of Figure 2 (dashed red lines). 
118 Figure 2. 3D block diagram of subsurface conditions in Montérégie Est (cross119 sections locations shown on Figure 1). The generally east-west cross-section goes 120 from the Lowlands to the Appalachian Uplands and crosses the thrust faults of the 121 Appalachian Front. The generally north-south cross-section remains in the 122 Lowlands but crosses a Monteregian Hill. Till (green) covers most of the bedrock, 123 with local accumulations of fluvio-glacial sediments (orange) or old Quaternary 124 sediments (brown), and is apparent at surface in the Appalachian Piedmont and 125 Uplands. Lacustrine (purple) and marine (light blue) fine sediments can form large 126 accumulations in the North Lowlands (more than $\mathbf{3 0} \mathbf{~ m}$ thick).

127 The St. Lawrence Lowlands occupy the sedimentary St. Lawrence Platform exhibiting a 128 low deformation and made up of Cambrian and Ordovician black and red shales, 129 dolostones and limestones (Clark et al. 1979; Globensky 1985). The northern part of the 130 Lowlands is covered by thick marine clay and silt deposits left by the Champlain Sea.

131 The maximum extension of the Champlain Sea basin is shown on Figure 1 (Parent and 132 Occhietti 1988). Occhietti and Richard (2003) corrected the ${ }^{14} \mathrm{C}$ ages obtained from sea 133 shells to establish the span of the Champlain Sea between about 13,000 to 11,000 years 134 before present. Fractured rock aquifers underlying these marine deposits that exceed $\sim 10$ 135 m thick contain brackish water. This area of non-potable confined groundwater extends 136 over $\sim 2,200 \mathrm{~km}^{2}$ (Beaudry et al. 2011; McCormack 1980), as shown on Figure 3. The 137 southern part of the Lowlands is covered by variable thicknesses and discontinuous units 138 of marine clay and till (Gaucher 1984; Prichonnet 1984) causing discontinuous and 139 variable groundwater confinement contexts (Figure 3).

Figure 3. Confinement level of the Montérégie Est fractured rock aquifer system 141 based on the nature and thickness of overlying sediments and extent of brackish 142 groundwater, to the north of the region.

143 The Appalachian Uplands correspond to the Internal Humber Zone of the Appalachians, 144 which are made up of Devonian ridge continental margin rocks highly deformed and 145 subjected to low-grade metamorphism (Slivitzky and St-Julien 1987; Brisebois and 
146 Nadeau 2003). Maximum elevation is approximately $500 \mathrm{~m}$ above sea level. The last 147 glaciations, from up to 16,000 years ago, eroded the summits and left behind glacial 148 valleys having a variable thickness of sediments and discontinuous till layers (Gaucher 149 1984; Prichonnet 1984). Groundwater is generally under unconfined conditions in high 150 elevation and semi-confined down the valleys (Figure 3). Apart from the northern partion 151 of the Lowlands, the surficial cover is usually less than $10 \mathrm{~m}$ thick, except in valleys. The 152 Appalachian Piedmont is located in between the Uplands and Lowlands. Its bedrock is 153 part of the Appalachian External Humber Zone, which is similar to that of the Uplands, 154 but surface sediments are similar to the southern part of the Lowlands. At the time of the 155 last glacial maximum, the Piedmont corresponded to the Champlain Sea shore as 156 illustrated in Figure 1. The fifth hydrogeological context corresponds to Monteregian 157 Hills, which are seven Cretaceous, mainly mafic, intrusives puncturing the other contexts 158 along a northwest-southeast axis. Erosion uncovered these plutons and geophysics 159 revealed the presence of several buried dykes around these hills (Feininger and Goodacre 160 1995; Séjourné et al. 2013). The Champlain Sea level did not reach the summit of most of 161 the hills.

162 Lands in the Lowlands and Piedmont are widely used for agriculture and also include a 163 few cities. Monteregian Hills and Uplands are less populated, activities are rural, and the 164 forest cover is more important. Average annual total precipitation for Montérégie Est is 165 approximately $1,100 \mathrm{~mm}$ /year and average temperature is $5.9{ }^{\circ} \mathrm{C}$, based on 16 weather 166 stations, for the period from 1970 to 1999 (Carrier et al. 2013). For the Uplands, the 167 average precipitation is generally higher and average temperature is generally lower. 168 Evapotranspiration is relatively constant for the entire region and is equivalent to about 169 half of total precipitation (Carrier et al. 2013).

170 Despite the in-depth interpretation of existing and additionally acquired geological and 171 hydrogeological data (described in Carrier et al. 2013), several questions remained about 172 the regional flow system in order to define a more representative conceptual model. The 173 geochemical and isotopic groundwater data were thus expected to provide information on 174 the following remaining issues related to the flow system: 
175 Even though recharge was estimated using the infiltration model HELP (Schroed-

176 er et al. 1994; Croteau et al. 2010; Carrier et al. 2013), the location of groundwa177 ter recharge and discharge zones needed to be confirmed through the geochemical 178 and isotopic signatures respectively associated with young and evolved ground$179 \quad$ waters (Tóth 1999);

180 - Although numerical simulations of the flow system have predicted the presence of 181 nested "Tothian" (Tóth 1963) local, intermediate and regional flow subsystems 182 (Laurencelle et al. 2013), the hydraulic conductivity of the regional aquifer ap183 peared to exponentially decrease with depth due to fewer open fractures as depth 184 increases (Laurencelle 2018). There was thus a need for field evidences that could 185 determine if groundwater flow is restricted to the shallow, more permeable part of 186 the rock aquifer or rather has a relatively deep regional component. The geochem187 ical signature of groundwater and especially its radiocarbon content were intended 188 to provide information on groundwater residence time, according to Plummer and 189 Glynn (2013), Clark (2015) and Han and Plummer (2016);

190 - Complementary to the determination of recharge and discharge zones, as well as 191 the occurrence of regional groundwater flow, there was also a question remaining 192 about the potential communication between the geological contexts present in the 193 study area. In particular, it was not known if the presence of the Monteregian 194 granitoids and their associated dyke network has caused a regionally more frac195 tured zone that would have favored long and deep flow paths between the Appa196 lachians Uplands and the adjacent Lowlands; 
- Finally, the impact of the marine invasion on groundwater outside of the 2,200 $\mathrm{km}^{2}$ area where brackish groundwater is found in the regional rock aquifer was unknown. The geochemical characterization was thus also meant to better understand the physical processes involved in the penetration of marine water in the regional rock aquifer and its following long-term leaching by fresh groundwater (Laurencelle 2018), as in other areas of the St. Lawrence Lowlands (Cloutier et al.

\section{Materials and Methods}

\section{Sampled boreholes}

206 [The characterization of groundwater geochemistry and isotopes was carried out through 207 the sampling of groundwater from boreholes (see next subsection), mostly installed in the 208 regional fractured rock aquifer that was the focus of the study. Some of the sampled 209 boreholes were drilled within the framework of the project (and are now integrated to the 210 observation well network of the Quebec Environment Ministry), but most of the 211 boreholes were private wells supplying households. All boreholes had a steel casing 212 across surficial sediments, which was anchored with a casing shoe at the top of the rock 213 aquifer, and the portion of boreholes through the rock aquifer was open and without 214 screens. Although the casing of observation wells was sealed through surficial sediments,

215 this is not generally the case for private wells as the sealing of casings has only become 216 mandatory in recent years.

217 Laurencelle (2018) and Carrier et al. (2013) provide information about the general 218 conditions of wells in the study area. Surficial sediment thickness is more important in 219 the Lowlands (5 to $20 \mathrm{~m}$ ) compared to the Appalachians (2 to $10 \mathrm{~m}$ ), which controls the 220 length of steel casing above the open hole section in the rock aquifer. Static water level is 221 generally around $5 \mathrm{~m}$ below ground and rarely exceeds $10 \mathrm{~m}$. Boreholes are relatively 222 shallow, being generally less than $50 \mathrm{~m}$ deep in the rock aquifer, although boreholes can 
223 be deeper in the Appalachians. Hydraulic conductivity ranges from about $10^{-6} \mathrm{~m} / \mathrm{s}$ in the 224 shallow part of the rock aquifer to about $10^{-8} \mathrm{~m} / \mathrm{s}$ at a depth of about $50 \mathrm{~m}$ in the rock

225 aquifer, due to the decrease in the occurrence of open fractures with depth. However, 226 there is a lot of variability in fracturing and thus in hydraulic properties.

227 Jackson and Heagle (2016) have warned about the limitations of using private wells for 228 the purpose of assessing baseline groundwater quality in relation with shale gas 229 exploitation. However, at the regional scale it would be prohibitive to install boreholes 230 dedicated to the establishment of groundwater geochemistry to obtain an adequate spatial 231 coverage. McIntosh et al. (2014) have actually shown that the sampling of private wells 232 could provide very important data about regional groundwater geochemistry. Still, the 233 implications of using open boreholes to sample groundwater have to be recognized. An 234 important implication is that groundwater samples represent aggregates of groundwater 235 coming from different depths in the rock aquifer. The shallow part of the rock aquifer 236 being more fractured and permeable, it is likely that more active groundwater flow could 237 take place in that zone where more recently recharged groundwater could be present. 238 Another implication is that preferential infiltration could take place along the steel casing 239 and affect the groundwater geochemistry. However, very few wells actually have a 240 geochemical signature that would indicate anthropic contamination, such as the presence 241 of nitrate (Carrier et al. 2013; Beaudry, 2013). Furthermore, results presented in this 242 paper show groundwater geochemistry that is coherent with the hydrogeological context, 243 such as the presence of reducing groundwater under confined conditions and radiocarbon 244 proportions indicative of the dominance of evolved groundwater with a long residence 245 time. Thus, the nature of sampled wells found in the study area did not preclude the 246 definition of representative groundwater geochemical conditions.]

\section{Data Collection}

248 [Groundwater from 206 wells drilled into the regional fractured rock aquifer was sampled 249 in 2010 and 2011, including 178 private wells and 28 observation wells. Each sample is 250 representative of the complete water column of the well and was sampled according to a 251 standard sampling procedure (Beaudry 2013; Carrier et al. 2013). The analytical program 
252 for each sample included physicochemical parameters and major, minor, and traces 253 inorganic elements such as alkalinity, 30 metals, nutrients and sulfur. Stable isotopes of 254 water $\left(\delta^{2} \mathrm{H}\right.$ and $\left.\delta^{18} \mathrm{O}\right)$ were analyzed for a subset of 90 samples. Tritium $\left({ }^{3} \mathrm{H}\right)$ and 255 radiocarbon $\left({ }^{14} \mathrm{C}\right.$-DIC) were analyzed as indicators of groundwater residence time on 44 256 and 43 samples, respectively, but 5 of the ${ }^{14} \mathrm{C}$ analyses were on samples with poor ionic 257 balance that were not included in the geochemical interpretation (there are 3 more ${ }^{3} \mathrm{H}$ and 2584 more ${ }^{14} \mathrm{C}$ analyses than reported by Beaudry 2013). The selection of samples for 259 isotopic analyses was based on the aim to cover the different hydrogeological contexts, as 260 well as on knowledge of the area. After verification of the availability of isotopic 261 analyses for the water types that are defined later in this paper, the addition of three ${ }^{3} \mathrm{H}$ 262 and four ${ }^{14} \mathrm{C}$ analyses was done to better characterize all water types.

263 Geochemical results were compiled into a database, including the site geographic 264 location, well ID that refers to the full well description in the hydrogeological database, 265 and the analytical method used. Concentration of carbonate and bicarbonate ions, TDS, 266 hardness, and ionic balance (in meq/L) were determined using simple equations in a 267 spreadsheet (Beaudry 2013). The ionic balance acceptance limit was fixed at $\pm 15 \%$ for 268 further use of geochemical results. A total of 19 samples exceeded that limit; they were 269 therefore rejected at first, then treated separately and considered for the interpretation. All 270 results reported as "undetected" (below the detection limit imposed by the analytical 271 method) were replaced by a value corresponding to $50 \%$ of the detection limit (Sanford et 272 al. 1993).]

\section{Data Interpretation Techniques}

274 [A statistical method based on Cloutier et al. (2008) was first used to sort all results due 275 to the large amount of geochemical data. As suggested by Güler et al. (2002), the 276 multivariate statistical techniques were combined with graphical hydrogeochemical 277 interpretation to meet the objectives of the study.

278 Multivariate Statistical Analysis (MSA) can be done with a combination of physical and 279 chemical parameters. Parameters considered in the present study were selected based on 280 three criteria: 
- $\quad$ Parameters available for most of the samples;

- A maximum of $10 \%$ of a parameter with undetected concentrations;

284 The 16 parameters selected were $p H, T D S$, pe, $\mathrm{HCO}_{3}, \mathrm{NH}_{4}, \mathrm{Ba}, \mathrm{B}, \mathrm{Ca}, \mathrm{Cl}, \mathrm{Mg}, \mathrm{Mn}, \mathrm{K}, \mathrm{Si}$, $285 \mathrm{Na}, \mathrm{S}$ and $\mathrm{SO}_{4}$. Then, the selection of samples for the MSA was also based on two types 286 of criteria:

287 - Availability of values for all 16 selected parameters;

288 - Acceptability of the ionic balance (within $\pm 15 \%$ ).

289 Results for 190 specific samples from bedrock wells having each 16 specific parameters, 290 constituted the input file for the MSA (190 x 16 matrix) (available in Beaudry 2013).

291 Hierarchical Cluster Analysis (HCA) MSA method was initially carried out with 292 Statistica 6.1® (StatSoft Inc. 2004) to group data into families having common 293 characteristics (Davis 1986). To do so, Ward's method was selected as a linkage rule, 294 with Euclidian distances as similarity measurement as done by Cloutier et al. (2008). This 295 analysis provides a tree diagram representing the linkage distance between each sample. 296 This diagram starts with a single cluster including all samples with zero loss of 297 information. When two clusters are joined, information is lost since differences within a 298 given cluster are disregarded. A phenon line, determined by visual inspection, is used to 299 find the right compromise between loss of information and a manageable number of 300 groups.

301 Then, the Principal Components Analysis (PCA) MSA method was carried out with the 302 same data matrix. PCA is a statistical method used to observe trends in a multivariate 303 dataset. It simplifies the understanding of the significance of the 16 parameters by 304 creating new components (called principal components) that better explain the variability 305 of the chemical composition between samples (Davis 1986). PCA also helps identify 
306 relationships between water groups. Results of the PCA are presented in terms of loading

307 values. Only the most significant components were kept for the interpretation. ]

308 Results

\section{Multivariate Statistical Analysis}

310 [At a linkage distance (phenon line) of 18, the cluster analysis defined 8 water groups 311 (Figure 4A). Figure 4B shows that the spatial distribution of these water groups is 312 generally coherent with the hydrogeological contexts of the region (Figures 1 and 2) and 313 corresponds well to the area where brackish groundwater is found (Figure 3). The names 314 assigned to these water groups are related to their geochemistry (Figure 5) and their 315 spatial distribution, which will be further discussed later (Figure 4B): A1 (light blue), A2 316 (blue) and A3 (purple) are water groups associated with the Appalachians (Uplands and 317 Piedmont); M1 (red), M2 (orange) and M3 (yellow) are Monteregian and "Mixed" types 318 of water groups; the CS (light green) water group is close to the original Champlain Sea 319 water geochemistry; and the LL (green) water group mostly occupies the Southern part of 320 the Lowlands. Colors assigned to water groups are the same for all graphs presented in 321 the paper.

Figure 4. Results of multivariate statistical analysis of geochemical parameters. A) 323 Cluster Analysis tree diagram defining the 8 water groups below a phenon line of

18. B) Spatial distribution of the 190 samples with colored areas belonging to a water group. C) Values of the $1^{\text {st }}$ and $2^{\text {nd }}$ components of the Principal Component Analysis for the 190 samples identified with their water group. The names of water groups were assigned on the basis of their spatial distribution (Figure 4B) and their geochemical characteristics (Figure 5): three "Appalachian" groups A1, A2 and A3; a "Southern Lowland" group LL; a "Champlain Sea" group CS; and three "Mixed" or "Monteregian" groups M1, M2 and M3.

331 Table 1 presents loading values of each parameter for the first 5 components of the PCA.

332 Components 1 and 2 explain together more than $61 \%$ of the variance. The third 333 component only adds $8 \%$ and was therefore neglected as well as subsequent components. 
334 The principal component scores for these first two components from each sample 335 (associated to one of the 8 water groups by a color) are illustrated in Figure 4C. This 336 graph shows that water groups defined by clustering have distinct and coherent global 337 geochemical characteristics according to the first two principal components obtained 338 from PCA. through C5) of the Principal Component Analysis (bold values indicate dominant parameters).

342 As illustrated in Figure 4C, cluster analysis and PCA provide together a first basis for

343 data interpretation. By considering the important loading values of TDS and other salinity

344 parameters (Table 1), the $1^{\text {st }}$ component can be interpreted as a combination of both fresh

345 and saline water. Saline waters have negative $1^{\text {st }}$ component values whereas low salinity

346 water has positive values. The $2^{\text {nd }}$ component seems to be associated with hardness

347 (Table 1). Negative values of the $2^{\text {nd }}$ component correspond to high calcium $(\mathrm{Ca})$ and

348 magnesium (Mg) concentrations, thus high hardness, whereas high positive values

349 correspond to sodium $(\mathrm{Na})$ concentrations larger than those of $\mathrm{Ca}$ and $\mathrm{Mg}$. This graph

350 will also be discussed later to support the interpretation of groundwater origins and

351 geochemical evolutions after further describing the geochemical characteristics of water 352 groups.]

\section{Geochemical Characteristics and Spatial Distribution of Water Groups}

354 [Descriptive statistics were calculated for each of the 8 water groups (Beaudry 2013). The 355 complete geochemical data set can be found in electronic format in Beaudry (2013) and 356 can be accessed online. Several hydrogeochemical graphs distinguishing water groups 357 were used to illustrate the distinct geochemical natures of water groups and help 358 understand the mechanisms responsible for the geochemical evolution of groundwater in 359 the fractured rock aquifer system.

360 Based on the water groups defined by HCA, median geochemical characteristics of water 361 groups were defined. Table 2 summarizes the median values of physico-chemical 
362 properties and component concentrations for the water groups. The median 363 concentrations, calculated for each major ion, provide an indication of the geochemical 364 profile of each water group. To help visualize differences between water groups, Figure 5 365 shows the proportions of major ion concentrations on a Piper diagram for each sample 366 (Figure 5A), and the average concentrations of major ions on Stiff diagrams for each 367 group (Figure 5B). The implications of the general geochemical composition of water 368 groups illustrated by Figure 5 will also be discussed in this section in relation with the 369 spatial distribution of each water group represented on Figure 4B. The pH and pe will 370 also be mentioned to better describe the geochemical conditions characterizing water 371 groups (Figure 6A). The extent of water group polygons were defined on the basis of 372 each of the 190 rock aquifer groundwater samples (location and water group), but also by 373 considering groundwater flow directions indicated by the potentiometric map (Carrier et 374 al. 2013). ]

375
Table 2. Median values of physico-chemical parameters and component concentrations $(\mathrm{mg} / \mathrm{L})$ for the water groups defined in Figure 4 (geochemical data and water group statistics are available in Beaudry 2013).

Figure 5. Major ions in groundwater. A) Proportions of major ions for each sample, associated with its water group (color) (defined in Figure 4), represented on a Piper diagram. B) Median ionic composition for each water group represented by Stiff diagrams (ions represented and concentration scale shown to the left of diagrams). The order of Stiff diagrams is based on relations between water groups and geochemical evolution paths that will be discussed in the section on Major Geochemical Processes.

\section{Brackish water groups CS and M3}

[The brackish groundwater area, located in the Northern Lowlands, is associated with water groups CS (Champlain Sea) and M3, which are characterized by significant concentrations of $\mathrm{Na}^{+}$and $\mathrm{Cl}^{-}$in areas under confined conditions (Figure 3). CS waters 
390 are found at the northern extremity of the study area, whereas M3 waters are found in the

391 southern part and eastern fringe of the brackish groundwater area. The CS group is 392 dominated by the $\mathrm{Na}^{+}, \mathrm{Cl}^{-}$, and $\mathrm{SO}_{4}{ }^{2-}$ ions (Figure 5B; Table 2), and has the highest 393 concentrations of total dissolved solids (TDS) as well as reducing conditions (Figure 6A).

394 The M3 group is dominated by $\mathrm{Na}^{+}, \mathrm{HCO}_{3}{ }^{-}$and $\mathrm{Cl}^{-}$ions (Figure 5B; Table 2) and is less 395 concentrated in TDS than the CS group, but it is quite alkaline (Figure 6A). M3 has the 396 highest $\mathrm{HCO}_{3}{ }^{-}$concentrations of all water types. CS waters show significant 397 concentrations of $\mathrm{Sr}, \mathrm{Fe}, \mathrm{As}, \mathrm{S}, \mathrm{B}$ and $\mathrm{Mn}$, in decreasing order of importance relative to 398 concentrations found in the study area (Table 2). M3 waters have relatively high 399 concentrations of F, Ba, B and As (Table 2). CS and M3 waters are non-potable.]

$400 \quad$ Monteregian and mixed water groups (fresh and saline) M1, M2 and LL

401 [The area containing brackish groundwater is surrounded by water groups M1 and M2 402 and, further south and east by LL water group in the Southern Lowland and north403 western part of the Piedmont. M1 and M2 waters are found in areas that are confined or 404 semi-confined, whereas LL waters are found under semi-confined and unconfined 405 conditions. The M1 group has the most alkaline waters of the study area (Figure 6A) and 406 is dominated by $\mathrm{Na}^{+}$and $\mathrm{HCO}_{3}{ }^{-}$ions (Figure 5B; Table 2). M1 waters have extremely 407 low concentrations of $\mathrm{Ca}^{+}, \mathrm{Mg}^{2+}$ and $\mathrm{Mn}^{2+}$, but have relatively high concentrations of $\mathrm{F}$

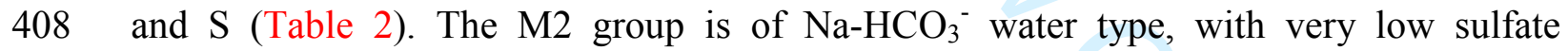
409 concentrations, but relatively high concentrations of $\mathrm{Ba}, \mathrm{F}, \mathrm{S}$ and $\mathrm{Sr}$ (Table 2). The LL 410 water group has a $\mathrm{Ca}^{2+}-\mathrm{HCO}_{3}{ }^{-}$water type, which is common for recently recharged 411 groundwater, as indicated by the relatively low residence time of these waters (discussed 412 later). LL waters have a relatively high TDS average concentration that is indicative of a 413 remnant of Champlain Sea water signature. LL waters have relatively high concentrations 414 of $\mathrm{SO}_{4}, \mathrm{Fe}, \mathrm{Mn}, \mathrm{Si}$ and $\mathrm{Ba}$ and variable concentrations of $\mathrm{Cl}$ (Table 2). The $\mathrm{Si}$ 415 concentration of LL waters are actually the highest of the water groups found in the study 416 area, which are inferred to be related to a slow water infiltration rate through thick till 417 deposits.] 
419 [The Appalachian groups (A) have quite distinctive geochemical conditions relative to 420 other water groups. Group A1 waters are of $\mathrm{Ca}-\mathrm{HCO}_{3}$ water type, which is consistent 421 with recent recharge and as shown by tritium and ${ }^{14} \mathrm{C}$ data (discussed later). A1 waters 422 are found mostly in the south-east of the Appalachian Uplands and in Monteregian Hills 423 that are mostly under unconfined to semi-confined conditions. The low $\mathrm{pH}$ and high pe of 424 A1 indicate oxidizing and acidic conditions (Figure 6A). Water groups A3 and A2 are 425 relatively more evolved waters, compared to $\mathrm{A} 1$, although $\mathrm{A} 3$ is still a $\mathrm{Ca}-\mathrm{HCO}_{3}$ water 426 type, whereas $\mathrm{A} 2$ is a $\mathrm{Na}-\mathrm{HCO}_{3}$ water type. A3 waters are dominant in the Appalachian 427 Uplands and in the north-east part of the Piedmont, which are under semi-confined or 428 unconfined conditions. A2 waters have relatively high concentrations of $\mathrm{Mn}, \mathrm{Fe}, \mathrm{S}$ and 429 As (Table 2). Water group A2 is found mostly at the western fringe of the southern half 430 of the Piedmont, as well as on Monteregian Hills. A2 waters are mostly found within the 431 limit of the Champlain Sea maximum transgression (Figure 4B). A2 waters have 432 relatively high concentrations of F, S, Mn and U (Table 2).]

\section{Major Geochemical Processes}

\section{Geochemical Conditions}

436 [Figure 6 presents four geochemical graphs further illustrating the geochemical nature of 437 water groups and allowing an interpretation of important geochemical processes 438 occurring in this study area. Figure 6A shows variations of $\mathrm{pH}$ (log of hydrogen activity) 439 and pe (log of electron activity) for all water groups (see also Table 2), which are good 440 indicators of groundwater conditions and evolution. Figure 6A shows the median values 441 of pe and $\mathrm{pH}$ for each water group, as well as the main range of values ("error bars" 442 indicate the values of the $25^{\text {th }}$ and $75^{\text {th }}$ percentiles). Each water group identified in 443 Montérégie Est shows pe values from mildly to strongly reducing waters (Hounslow 444 1995). Water groups are positioned in Figure 6A according to the spatial associations of 445 water groups and their inferred geochemical evolution path based on residence time 
446 indicators (discussed in section on Water Origins and Ages) and other further elements

447 discussed in the present section or the next. The A1 water group shows the most

448 oxidizing conditions with the highest dissolved oxygen concentration (Table 2), which

449 are consistent with a typical $\mathrm{Ca}-\mathrm{HCO}_{3}$ recharge water type. On the other hand, the CS

450 water group has strongly reducing conditions, with the lowest dissolved oxygen

451 concentration (Table 2).

452 The geochemical processes further discussed here are the mixing of brackish water with

453 fresher waters, carbonate dissolution and ionic exchanges between $\mathrm{Na}^{+}$and $\mathrm{Ca}^{2+}$ ions.

454 Since the former presence of the Champlain Sea over the study area exerts an important

455 control over groundwater geochemistry in Montérégie Est, the origin of groundwater

456 salinity will first be discussed.]

Figure 6. Geochemical conditions for the water groups found in Montérégie Est. A) Average pe and pH values for the eight water groups. B) Champlain Sea water mixing. C) Carbonate dissolution indicated by a $\mathrm{Ca} / \mathrm{HCO}_{3}$ ratio (in $\mathrm{mmol} / \mathrm{L}$ ) of 1:2 (dashed line). D) Evidence of groundwater freshening due to Na-Ca ion exchange.

\section{Origin of Groundwater Salinity}

462 [The study area was in large part covered by the Champlain Sea approximately 13,000 to 46311,000 years ago (Occhietti and Richard 2003; see Figure 1 for marine limit). As 464 demonstrated by Cloutier et al. (2010) for an area located $80 \mathrm{~km}$ west of Montérégie Est,

465 the Champlain Sea water could have invaded the fractured rock aquifer and impart an 466 important geochemical signature on groundwater. Cloutier et al. (2010) show that the 467 Champlain Sea water was $34 \%$ sea water mixed with $66 \%$ of fresh water from melting 468 glaciers and precipitation. Their calculation was based on the $\mathrm{Br} / \mathrm{Cl}$ ratio that remained 469 constant in the sea water, with original concentrations of $0.8385 \mathrm{mmol} / \mathrm{L}$ of $\mathrm{Br}$ for 535.92 $470 \mathrm{mmol} / \mathrm{L}$ of $\mathrm{Cl}$. Based on the numerical modelling of marine water invasion of the rock 471 aquifer, Laurencelle (2018) suggests that the Champlain Sea may have had a normal 472 marine water concentration, with dilution occurring in the aquifer rather than sea. 473 Figure $6 \mathrm{~B}$ shows the $\mathrm{Br}$ versus $\mathrm{Cl}$ concentrations (in $\mathrm{mmol} / \mathrm{L}$ ) for groundwater sampled 474 in the study area. The black cross represents the global sea water composition (Hem 
475 1985), the white circle represents sample S77 found in the Cloutier et al. (2010) study 476 area that is considered representative of the Champlain Sea water composition after 477 mixing with fresh water. Samples from water groups CS and M3 plot close to the dashed 478 dilution line: between Champlain Sea water and fresh water, which means that the 479 brackish area in the north of Montérégie Est originated from the Champlain Sea invasion. 480 The CS group composition is similar to the diluted Champlain Sea composition and the 481 M3 group is further diluted sea water with fresh water. So, the CS water group is 482 considered as an end-member representing the original composition of brackish 483 Champlain Sea water in the regional rock aquifer in the areas formerly covered by the sea 484 (Figure 4). ]

\section{Carbonate Dissolution}

486 [Limestones and dolomites contain $\mathrm{Ca}$ and $\mathrm{Mg}$ minerals (responsible for the water 487 hardness) that dissolve relatively easily in groundwater, especially in recharge areas, 488 where low pH rainwater infiltrates in the aquifer (Appelo and Postma 2005; Clark 2015). 489 Beaudry (2013) found that saturation indexes of dolomite and calcite (both carbonates) 490 were especially under-saturated with respect to carbonates for group A1, which means 491 that if carbonates are present in the aquifer, they will potentially dissolve. Group LL 492 seems to be more in equilibrium with dolomite and somewhat under-saturated with 493 respect to calcite. Calcite $\left(\mathrm{CaCO}_{3}\right)$ dissolution occurs according to the following reaction:

$$
\mathrm{CaCO}_{3}+\mathrm{CO}_{2}+\mathrm{H}_{2} \mathrm{O} \leftrightarrow \mathrm{Ca}_{2}{ }^{+}+2 \mathrm{HCO}_{3}{ }^{-}
$$

495 This reaction explains why the type of water associated with recharge is generally $\mathrm{Ca}^{2+}-$ $496 \mathrm{HCO}_{3}-$. Water groups $\mathrm{LL}$ and $\mathrm{Al}$ are good examples of the carbonate dissolution 497 mechanism as shown by the $\mathrm{Ca}$ versus $\mathrm{HCO}_{3}$ graph of Figure $6 \mathrm{C}$. Water groups $\mathrm{A} 3$ and 498 M2 also seem to be affected by calcite dissolution, but with less intensity.

499 The mechanism of carbonate dilution controls $\mathrm{Ca}$ and $\mathrm{HCO}_{3}$ concentrations for water 500 group A1, while other processes may influence these concentrations for water group LL. 501 Both groups are located in unconfined to semi-confined conditions in areas contributing 502 to the regional aquifer recharge (Carrier et al. 2013). Water groups A1 and LL are thus 
503 both considered as end-members representing fresh recharge water input into the regional

504 rock aquifer system, even though LL is also subject to mixing with sea water. ]

506 [Calcium concentration, relative to sodium, increases due to carbonate dissolution as 507 discussed previously. On the other hand, sources of sodium are limited to sea water 508 (characterized by halite dissolution, $\mathrm{NaCl}$ ), some silicates and a few rarer minerals 509 (Hounslow, 1995). Water group CS represents sea water with a significant TDS and 510 sodium (Na) concentrations (Figure 5; Table 2). Water group LL is partly the result of 511 mixing between fresh water with geologic influence and to a lesser extent sea water.

512 However, freshening due to $\mathrm{Na}-\mathrm{Ca}$ ion exchange is responsible for the radical increase of 513 sodium relative to calcium (Figure 6D), which occurs with a limited increase in TDS 514 concentration (not shown), especially for water groups M1 and A2.

515 Some of the aquifer materials such as clay minerals (abundant in shales of the Lowlands; 516 Globensky 1985), organic matter, and metal oxy-hydroxides have the property to sorb 517 ions (Appelo and Postma 2005; Clark 2015). An adherence is created between cations 518 and the solid surface of the material. This is called the adsorption phenomenon. Under 519 steady-state chemical conditions, the exchanger (site of adsorption) is occupied by the 520 dominant cations. In fresh aquifers, $\mathrm{Ca}^{2+}$ is often dominant. When sea water infiltrates the 521 aquifer, $\mathrm{Na}^{+}$becomes a dominant cation and gets adsorbed. When freshening occurred, 522 after the Champlain Sea had receded, $\mathrm{Ca}^{2+}$ moved $\mathrm{Na}^{+}$out of the exchanger to get re523 adsorbed. The consequence of this ionic exchange, called freshening, is a rise in the 524 amount of sodium found in solution, accompanied by a drop in calcium concentration as 525 shown by Figure 6D. Those Na-rich water groups (M1, M2, M3 and A2) are generally 526 associated with confined to semi-confined conditions, in bedrock containing clay 527 minerals, inside the Champlain Sea transgression limit (Figure 4B). The M1 group has 528 the highest freshening level and, although it is not an end-member representing a 529 provenance of groundwater, it represents the ultimate state of groundwater evolution due 530 to $\mathrm{Na}-\mathrm{Ca}$ ion exchange. 
531 Na-Ca ion exchange occurs during the flushing by newly recharged fresh water into parts 532 of the aquifer system that were formerly invaded by high salinity marine water $(\mathrm{Na}-\mathrm{Cl}$ 533 water type). Thus, the freshening process at the origin of $\mathrm{Na}-\mathrm{Ca}$ ion exchange also 534 involves the mixing of fresh $\mathrm{Ca}-\mathrm{HCO}_{3}$ recharge water with $\mathrm{Na}-\mathrm{Cl}$ water having a high 535 salinity. It follows that the sum of cations in groundwater that has undergone these 536 combined processes has a higher sum of cations (ultimately only $\mathrm{Na}$ ) than the sum of 537 cations that were present dominantly as $\mathrm{Ca}$ in the fresh recharge water, even though that 538 water has an increased concentration in $\mathrm{Ca}$ as it evolves and further dissolves calcite 539 along its flow path. This is seen by the larger concentration of $\mathrm{Na}$ relative to $\mathrm{Ca}$ in Figure 540 6D. When comparing water group A3 that evolves into water group A2, which is 541 subjected to $\mathrm{Na}-\mathrm{Ca}$ ion exchange, the sum of $\mathrm{Ca}$ and $\mathrm{Na}$ ions stays relatively constant 542 between 2 and $5 \mathrm{meq} / \mathrm{L}$. However, when $\mathrm{Na}$ becomes the dominant cation and shows sign 543 of mixing with marine water (higher $\mathrm{Cl}$ ), then the sum of cations increases.]

\section{Mixing and Relations Between Water Groups}

545 [Figure 7A shows again samples from water groups relative to the $1^{\text {st }}$ and $2^{\text {nd }}$ components 546 of the PCA. This graph is used here to illustrate mixing and geochemical evolution 547 between water groups. This graph also identifies the inferred groundwater end-members 548 recognized in the study area, as suggested by Valder et al. (2012).

Figure 7. Mixing and relations between water groups and groundwater geochemical end-members. A) Samples of water groups defined in Figures 4 and 5 according to the $1^{\text {st }}$ and $2^{\text {nd }}$ components of the Principal Component Analysis (PCA). B) Relative concentrations of major cations (X-axis) and major anions (Y-axis), similar to a Piper plot, supporting relations shown on the PCA graph. Inferred geochemical end-members are superposed on both graphs: Sea Water, Lowland Recharge, Monteregian Water and Appalachian Recharge. These end-members are positioned at the limits of principal components $(7 \mathrm{~A})$ or ion ratios $(7 \mathrm{~B})$ representing the general range of end-member values.

558 By associating the first component of Figure 7A with salinity and TDS, the mixing 559 process can be described. TDS, or salinity, decreases from the left side of the graph to the 
560 right: between brackish compositions of the CS end-member (Champlain Sea water), to 561 the fresh water of the A1 end-member (recharge in the Appalachians). The A1 group is 562 characterized by the lowest TDS concentrations among water groups. The LL end563 member is found between the A1 and the CS groups. The LL water group features similar 564 characteristics as A1 (recharge water with low $\mathrm{pH}$ and calcite dissolution mechanism), 565 but with a much higher TDS, representative of diluted sea water. The mixing with 566 residual Champlain Sea water (which is still potentially trapped in the rock aquifer and 567 overlying till) and the presumed slow flow where topography is nearly flat, could explain 568 the high TDS concentrations of the LL group that still bears the geochemical signature of 569 the Champlain Sea water.

570 The same reasoning can be applied to major ions shown in Figure 7B. Similar to the 571 traditional Piper diagram, the $\mathrm{X}$-axis shows relative concentrations in major cations and 572 the Y-axis shows the relative concentrations of major anions (in percent and calculated in $573 \mathrm{meq} / \mathrm{L}$ ). Three circles (with a continuous line) identify the 3 end-members, A1, LL, and 574 CS. Based on the ionic composition of these groups, the LL water group plots between 575 the two others, supporting the mixing hypothesis introduced earlier, although the fact that 576 LL represents recently recharged water makes it also an end-member.

577 The $2^{\text {nd }}$ component of PCA of Figure 7A has been associated to hardness. The figure 578 shows how M1 (red), M2 (orange), M3 (yellow), and A2 (dark blue) groups have 579 important differences in their hardness, which have been related to a freshening 580 mechanisms compared to other groups. The M1 group is associated with the highest level 581 of $\mathrm{Ca}-\mathrm{Na}$ ion exchange; it is identified as a water evolution end-member, with a dashed582 line circle. The freshening is also clearly identified in Figure 7B where sodium-rich 583 waters are found in the top left corner of the graph. Based on the fact that the highest 584 concentration of sulfates and chlorides are associated with the CS water type, we can 585 presume that vertical variations on that graph are mainly explained by its mixture with 586 sea water (brackish or residual).

587 Therefore, water group M3 is probably a mixture, or an overlap of groups M1 and CS. 588 For the same reasons, M2 is probably a mixture of groups M1 and LL. Geographically, 
589 such mixing makes sense. Due to the geographic distance between A2 and M1, A2 is not

590 a mixture between A1 and M1. These relations will later be reviewed in the conceptual 591 model section. ]

593 Water Origins and Age

\section{Water Origins}

595 [As a part of the water cycle, groundwater can be characterized according to its isotopic 596 composition $\left(\delta^{2} \mathrm{H}\right.$ and $\left.\delta^{18} \mathrm{O}\right)$ (Clark and Fritz 1997). A comparison with local meteoric 597 water lines (LMWL) can help understand water origin in terms of climate or altitude. The 598 most representative LMWL found for Montérégie Est is the one defined by Cloutier et al. 599 (2006) for the Basses-Laurentides region, located some $80 \mathrm{~km}$ to the west and with 600 similar elevations?. The Basses-Laurentides meteoric water line (BLMWL) and isotopic 601 composition of samples from the eight water groups of Montérégie Est are displayed in 602 Figure 8A.

603 Based on the previously mentioned two third dilution hypothesis of the Champlain Sea 604 water (Cloutier et al. 2010), it is expected that the CS water group will be a mixture of 605 low isotope fractionation water (sea water; VSMOW of $\delta^{2} \mathrm{H}=0 \%$ and $\delta^{18} \mathrm{O}=0 \%$ ) and 606 high isotope fractionation water (melting glaciers and precipitation at high latitude). 607 According to Figure 8A, the CS water group, as well as the Lowlands-related water 608 groups M2, M3 and LL, plot near the top of the graph, with the lowest isotopic $\delta^{2} \mathrm{H}$ and $609 \delta^{18} \mathrm{O}$ fractionation. On the other hand, water groups associated with topographic highs 610 (Monteregian Hills, Piedmont and Uplands), plot on the lower part of the graph, which is 611 representative of a recharge under colder conditions or at high altitude. The M1 water 612 group plots together with A1 to A3 water groups, which would support the hypothesis 613 that the M1 water group originates from mixing between fresh water recharged in the 614 Uplands and saline water from the Lowlands.] 
616 [Isotopic indicators of residence time can also help infer groundwater origin and

617 evolution of the water groups found in Montérégie Est and their interrelations. Tritium

618 and radiocarbon can provide such indications of groundwater residence time, respectively

619 for young water (less than about 50 years for tritium) and older water (up to 50000 years

620 for ${ }^{14} \mathrm{C}$ ) (Clark and Fritz 1997). Overall, 42 samples were analyzed for tritium and 43 for

621 radiocarbon, with 28 samples having both analyses. Figure 8B relates tritium and

622 uncorrected radiocarbon ages. Samples analyzed for only one of those two parameters are

623 also represented, in the left and bottom margins of the graph. Ranges of values obtained

624 for tritium and radiocarbon data for each water group are provided in Table 3.

625 Figure 8. Isotopic composition of groundwater. A) Stable isotopes of groundwater

626 by groups compared to the Basses-Laurentides meteoric water line (BLMWL;

627 Cloutier et al. 2006). B) Residence time of water groups indicated by tritium $\left({ }^{3} \mathbf{H}\right.$ is

628 in tritium units, TU) and radiocarbon (non-corrected ${ }^{14} \mathrm{C}$ ages in years before 629 present, BP). Samples analyzed for only one of the two parameters are represented 630 in the left and bottom margins of the graph. Ellipses indicate the distribution of 631 samples for water groups.

632 In order to have a better indication of the residence time that is representative of the 633 different water groups, radiocarbon data were interpreted according to the guidelines 634 provided by Han and Plummer (2016) and made use of the graphs proposed by Han et al. 635 (2012). Calculations of corrected radiocarbon ages were done using the interpretation 636 spreadsheet developed by Janos (2017). Basically this approach identifies the processes 637 affecting radiocarbon and uses the correction method suitable for these processes. The 638 interpretation graphs used for the correction of radiocarbon ages and results are 639 documented in a new appendix added to the thesis of Beaudry (2013), which is accessible 640 online. Table 3 summarizes the range of corrected ${ }^{14} \mathrm{C}$ residence times that were obtained 641 for all water groups, which are illustrated later in Figure 9B. Vautour et al. (2015) found 642 similar ranges of groundwater residence times in another area of the St. Lawrence 
643 Lowlands, although the maximum ages were not as high in their study area, which did 644 not include remnants of Champlain Sea water.

\section{Table 3. Ranges of tritium $\left({ }^{3} \mathrm{H}\right)$, uncorrected (lab.) and corrected ${ }^{14} \mathrm{C}$ ages for the} water groups.

647 Water groups LL and $\mathrm{A} 1$ have a $\mathrm{Ca}-\mathrm{HCO}_{3}$ water type that can be indicative of non648 evolved recent recharge groundwater (Clark and Fritz 1997; Cloutier et al. 2010). Data 649 from these water types plot on the top-left corner of the graph in Figure 8B, with over 10 650 tritium units (TU), uncorrected ${ }^{14} \mathrm{C}$ ages under 4000 years before present and corrected

$651{ }^{14} \mathrm{C}$ ages corresponding mostly to modern water (Table 3 ), which confirm they are young 652 groundwaters in recharge areas or that have had relatively short duration flow paths from 653 recharge areas. Both water groups show evidence of carbonate dissolution in an open $654 \mathrm{CO}_{2}$ system (appendix of Beaudry 2013), which is compatible with indications provided 655 by Figure $6 \mathrm{C}$ and the undersaturated conditions relative to calcite and dolomite (appendix 656 of Beaudry 2013), especially for water group A1.

657 At the other end of the age spectrum, Champlain Sea water group CS indicates 2 results 658 (radiocarbon only) of either uncorrected or corrected ${ }^{14} \mathrm{C}$ ages around 14,000 years, 659 which are quite consistent with the Champlain Sea period (13 to $11 \mathrm{ky}$ BP; Occhietti and 660 Richard 2003; Laurencelle 2018). Intermediate tritium and ${ }^{14} \mathrm{C}$ ages for water groups M2, $661 \mathrm{~A} 3, \mathrm{M} 1$ and A2 indicate the importance of young and old water mixing affecting the 662 residence time of these water groups, which allowed them to evolve geochemically. 663 Overall, Table 3 shows that the residence time increases from A1 to A3 and A2, which 664 would lead to more evolved waters. The increase in residence time from LL to M2, to M3 665 and to CS (Table 3) is consistent with groundwater evolution and mixing with old 666 Champlain Sea water. Corrected ${ }^{14} \mathrm{C}$ ages for water group M1 have the largest change 667 compared to uncorrected ages due to carbonate dissolution associated with $\mathrm{Na}-\mathrm{Ca}$ ion 668 exchange (Clark 2015). This process also affected the ${ }^{14} \mathrm{C}$ ages of water group A3 to 669 some extent. Water groups $\mathrm{A} 2$ and $\mathrm{A} 3{ }^{14} \mathrm{C}$ ages were affected by calcite precipitation, 670 which is consistent with their $\mathrm{pCO}_{2}-\mathrm{pH}$ relationship and their saturation indexes relative 671 to calcite (appendix of Beaudry 2013). 
672 The M1 water group is somewhat puzzling since it has relatively long residence times, 673 despite the presence of tritium showing some mixing with young groundwater. The M1 674 water group is mostly located near Monteregian Hills, which are presumed to represent 675 preferential recharge areas. A source of old groundwater that can only be from great 676 depth or long travel paths is thus needed to lead to such evolved groundwater among a 677 preferential recharge zone. Pinti et al. (2013) found larger helium in groundwater in the 678 Montérégie Est region compared to other parts of the St. Lawrence Lowlands between 679 Quebec City and Montreal. Such helium concentrations could represent a preferential 680 migration path from the Precambrian bedrock, which could perhaps result from the effect 681 of a large mafic dyke network associated with Monteregian Hills that are found over a 682 large part of Montérégie Est (Séjourné et al. 2013).]

\section{Geochemical evolution and residence time}

684 [Even though the geochemical evolution (Figures 6 and 7) and residence time (Figures 685 8B) of water groups have been discussed successively, the intent is here to briefly wrap 686 up the description of water groups by combining these two concepts. For that purpose, 687 Figure 9 shows one indicator of geochemical evolution $(\mathrm{Na} / \mathrm{Ca}$ in Figure $9 \mathrm{~A})$ versus the $688{ }^{14} \mathrm{C}$ uncorrected age (in order to show data from water groups $\mathrm{LL}$ and $\mathrm{A} 1$ that have 689 modern waters), which provides an indication of groundwater residence time. Figure 9B 690 graphically shows the corrected ${ }^{14} \mathrm{C}$ ages for each water groups to demonstrate that the 691 geochemical evolution illustrated in Figure 9A is quite coherent with the range of 692 residence times of the water groups. Figure 9A clearly shows that geochemical evolution 693 paths are distinct in the Lowlands and Appalachians, as the geochemical indicators are 694 quite different for the two domains. Also, Figures 9A and 9B show together that the level 695 of geochemical evolution stems directly from the groundwater residence time. Although 696 water groups are statistically different, there is a continuous evolution of groundwater 697 through time (as well as through space as shown by the distribution of water types in the 698 study area in Figure 4B). For instance, water groups A1, characteristic of recharge zones, 699 leads to older waters of group A3 found within the Appalachians, and then older and 700 more evolved still group A2 water, which is found in the Piedmont at the western edge of 701 the Appalachians. A similar, but not as clear, groundwater evolution path may relate 
702 recharge water represented by Lowlands LL water group with the M2 and M1 water 703 groups. Actually, the evolution path related to these water types are clearer in Figure 7, 704 which may indicate that water group M1 could be related as well to the Appalachian 705 groundwater evolution path as to the Lowlands evolution path. The relationships between 706 water groups and the implications of groundwater evolution paths are integrated in a 707 conceptual model of groundwater geochemical evolution in the next section.]

Figure 9. Geochemical evolution paths and residence time. A) $\mathrm{Na} / \mathrm{Ca}$ ratio versus uncorrected ${ }^{14} \mathrm{C}$ ages. B) Corrected ${ }^{14} \mathrm{C}$ age range of water groups (Table 3). Sample colors are related to water groups as defined in Figures $4 \mathrm{~A}$ and 5.

\section{Conceptual Model and Discussion}

712 [The integration of all available geochemical data and their interpretation provided the 713 basis for the development of a conceptual model of regional groundwater geochemical 714 evolution in the study area. Figure 10 summarizes the relations between all water groups 715 and represents the main mechanisms responsible for groundwater evolution.

Figure 10. Conceptual model of groundwater geochemical evolution in Montérégie Est. Each of the 8 water groups is represented with the direction of evolution (arrows), the main mechanisms involved (mixing, geological influence, ion exchange) and the corrected radiocarbon age range (see Table 3 ).

720 Figure 11 is a schematic representation of the Montérégie Est regional flow system based

721 on the hydrogeochemical interpretation made in the present study. The cross-section

722 starts from the Appalachian Uplands, to the east, goes through the Rougemont

723 Monteregian Hill, and then branches northward through the brackish groundwater zone,

724 towards the St. Lawrence River. Black arrows show groundwater flow directions. The 725 remainder of this section further describes the geochemical conceptual model and its 726 implications on the functioning of the regional aquifer system. 
are illustrated with associated colors and flow directions are represented by arrows. The limit of the former Champlain Sea is indicated by dashed lines on the map and section.

\section{Champlain Sea invasion area (Water groups CS, M1, M2, M3, LL and A2)}

733 The area of the aquifer system at lower altitude is still affected by the Champlain Sea 734 invasion (Northern and Southern Lowlands, Piedmont; Figures 1 and 11) and by slower 735 groundwater flow due to the generally flat topography. This area also has low aquifer 736 recharge (Carrier et al. 2013), especially in the northern part of the Lowlands under 737 confined conditions due to the relatively thick marine clay and silt cover (Figure 3). 738 Furthermore, important groundwater discharge seems to occur at the western edge of the 739 Piedmont, either due to a topographic effect or the presence of the thrust fault zone, so 740 the low-lying area further west or north-west does not receive a major contribution of 741 groundwater originating from the Uplands. The rock aquifer in the area within the limit

742 of the former Champlain Sea contains either brackish groundwater, which is well 743 preserved under confined conditions (CS water group) or water with traces of marine 744 influence under semi-confined to unconfined conditions (LL water group).

745 Groundwater within that area is also characterized by important concentrations of sodium 746 (and other residual marine components) in solution or adsorbed by the clay minerals of 747 the rock aquifer made up in large part of shales and mudstones. Groundwater freshening 748 occurs when fresh water mixes with brackish water in aquifers containing clay minerals 749 (water groups M1 and A2, see section "Geochemical Conditions"). When bedrock does 750 not contain clay minerals, or when freshening has already been completed, the mixing of 751 trapped or residual brackish water with fresh water occurs more as a simple dilution (LL 752 water group). Water groups M2 and M3 represent transition (or mixing) between those 753 three contexts, as also supported by ${ }^{14} \mathrm{C}$ ages (Table 3): well preserved brackish water 754 (CS with original Champlain Sea age; Table 3), freshening contexts (M1 and A2) and 755 brackish water simply diluted by the local recharge of fresh water with geologic influence

756 (LL). The local recharge is easily identified by young (modern ${ }^{14} \mathrm{C}$; Table 3) and fresh $757 \mathrm{Ca}-\mathrm{HCO}_{3}$ water, with relatively low $\mathrm{pH}$ and with a composition controlled by carbonate 
758 dissolution (LL). However, according to the geochemical characteristics, the LL water 759 group does not seem to be the fresh water source responsible for the water freshening 760 mechanism. The fresh water origin will be discussed next.

\section{High altitude areas (Water groups A1 and A3)}

762 High altitude recharge is affected by geologic influence, which is not overshadowed by 763 the high TDS concentrations of sea water as in the low altitude recharge areas. The 764 physiographic contexts associated with high altitude recharge are the Appalachian 765 Uplands (mainly south-east), the eastern and southern parts of the Piedmont and some of 766 the Monteregian Hills. This recharge water is associated with the presence of tritium 767 (typical of young water; Table 3), a Ca- $\mathrm{HCO}_{3}$ water-type with relatively low $\mathrm{pH}$ and with 768 a composition controlled by carbonate dissolution (A1). For water group A1, it is presumed that total dissolved solids slightly increase due to the relatively fast flow under unconfined to semi-confined conditions and the high topographic relief. On the other hand, A3 water group, which is more evolved and corresponds to longer residence time

772 water (Table 3), with higher TDS, is dominant in the Upland and the north-east of the 773 Piedmont, under semi-confined conditions as well as under unconfined conditions. As

774 expected, the TDS increase is caused by the dissolution of common minerals, generating 775 a moderate increase in the concentrations of major ion (Gibbs 1970). $\mathrm{pH}$ is also 776 increasing along flow paths, accompanied by the decrease of dissolved oxygen and pe 777 (Figure 6A). Two assumptions still remain to be verified relative to the origin of the A3 778 water group, considering the relatively long residence time of that group as indicated by $779{ }^{14} \mathrm{C}$ data (Table 3):

780 1. The presence of a long and relatively deep flow path in the Appalachians, 781 originating in part from the A1 water group, would lead to the evolution of the A3 782 water group having a long residence time, or either ;

783 2. The $\mathrm{A} 3$ water group represents the mixing between modern water with evolved 784 groundwater from another source (e.g. continuous upward release of groundwater 785 related to recharge at large depth of ice melting water from the last glaciation). 
787 The link between the high and low altitude systems, or the fresh water contribution, is 788 presumed to be made by the A2 and the M1 water groups, which, as discussed 789 previously, probably originate from high altitude zones. A2 water group would originate 790 from the A3 water group, which discharges in the Appalachian Piedmont into the former 791 Champlain Sea environment. M1 water group would originate in part from high altitude 792 recharge in the adjacent Monteregian Hills. A2 water group is observed in the Piedmont, 793 whereas M1 water group is locally present in the Southern Lowlands and especially 794 around some Monteregian Hills. The confluence of fresh water (A3) with the former 795 Champlain Sea environment involves ionic exchange mechanisms. The resulting water 796 type is characterized by an alkaline $\mathrm{Na}-\mathrm{HCO}_{3}$ water-type, with high sodium 797 concentrations and low calcium concentrations. The A2 water type is associated with a 798 lower level of ionic exchange and the M1 water type represents the highest level of 799 effects from ionic exchange which makes the M1 water type appear as an end-member 800 among water groups (Figures 7A and 7B).

801 Overall, the groundwater composition in Montérégie Est is largely related to the 802 hydrogeologic conditions (confined, semi-confined or unconfined) and to the Champlain 803 Sea influence (associated with topographic lows). This conceptual model of the 804 groundwater flow system (Figure 11) led to a revision of the initial conceptual model 805 based on hydrogeological data alone. For instance, the Piedmont is not a preferential 806 recharge area, as presumed initially at the onset of the project, but rather a discharge area 807 for deep Appalachian groundwater. Also, in the Appalachian Uplands, due to relatively 808 low hydraulic conductivity and the limited depth of natural fracturing, it was initially 809 presumed that groundwater flow would be of a limited vertical extent and therefore 810 strictly associated to young recharge groundwater, but on the contrary geochemical data 811 showed that relatively evolved groundwater with long residence times are found in the 812 uplands (A3), even though the origin of this water is not yet fully understood.

813 The residence time (evaluated with tritium and ${ }^{14} \mathrm{C}$ ages) increases from $\mathrm{A} 1$ to $\mathrm{A} 3$ and 814 A2 (Figures 8B and 9B, Table 3), which would lead to more evolved waters. The 
815 increase in residence time from LL to M2, to M3 and to CS (Figures 8B and 9B, Table 3)

816 is consistent with groundwater evolution and mixing with old Champlain Sea water. The

817 M1 water group has relatively long residence times, despite the presence of tritium

818 showing some mixing with young groundwater. An uncertainty still remains about the

819 actual origin of the M1 water group and the reason for its long residence time despite its

820 location near some preferential recharge areas of the Monteregian Hills. One potential

821 hypothesis is that deep waters upflowing along fractured Monteregian dykes could

822 impart the long ${ }^{14} \mathrm{C}$ residence times to this water type, even though the presence of

823 tritium also shows the contribution of recent recharge to this water type. As mentioned,

824 high helium concentrations (Pinti et al. 2013) in this area may provide indications that a

825 preferential migration pathway is present in the region, which would allow deep flow

826 originating from the Appalachians to reach not only the Piedmont (water group A2) but

827 also the center of the study area (water group M1) along the Richelieu River and around

828 Monteregian Hills (Figure 4B).]

\section{Conclusions}

830 [The multivariate statistical analysis of geochemical parameters from groundwater 831 samples in the Montérégie Est study area helped define water groups and understand 832 mechanisms controlling groundwater geochemistry. The identification of four end833 members (two recharge waters, A1 and LL, a brackish Champlain Sea water, CS, and a 834 geochemical evolution end-member, M1), the aquifer confinement levels and the limit of

835 the Champlain Sea paleo-environment appear to be the main elements controlling 836 groundwater geochemical evolution. Even if only a few geochemical mechanisms were 837 identified and discussed, it was demonstrated that ionic exchange and mixing have a 838 dominant influence on the overall groundwater composition. Isotopic data were useful to 839 support hydrogeochemical hypothesis. In particular, indications of residence times from 840 radiocarbon and tritium confirmed the long residence time of water groups having 841 indications of geochemical evolution and further supported their relationships.

842 This hydrogeochemical investigation significantly contributed to the understanding of the 843 regional flow system. The most important contributions that can be attributed to the 
844 interpretation of the geochemical results and that would likely have been missed solely

845 based on physical hydrogeological data, are the following:

846 - Identification of the areas of aquifer recharge, which are characterized by young

847 (high tritium and modern ${ }^{14} \mathrm{C}$ ) water with relatively low $\mathrm{pH}$ and with a composition

$848 \quad$ controlled by carbonate dissolution $\left(\mathrm{Ca}-\mathrm{HCO}_{3}\right.$ water);

849 - Delineation of a brackish (non-potable) water zone corresponding to a remnant of 850 Champlain Sea water that had invaded the rock aquifer. This zone is now under 851 fully confined conditions and without significant groundwater flow. The ${ }^{14} \mathrm{C}$ age of 852 this water corresponds to the Champlain Sea period;

853 - Identification of a potentially regional freshwater flow path, originating from the 854 Appalachian Uplands and emerging into the Piedmont and locally in the Lowlands 855 (around Monteregian Hills), which would be responsible for the freshening 856 mechanism. The geochemical data thus support the occurrence of Tothian nested 857 flow systems of local, intermediate and regional scales;

858 - Evidences that the Piedmont is not a preferential recharge area as presumed initially 859 at the onset of the project, but rather a regional discharge area for relatively deep 860 Appalachian groundwater flow with long residence time, which emerges at the 861 Appalachian's western edge, in the vicinity of the thrust fault zone;

862 - Development of a conceptual model of the groundwater flow system integrating the 863 geochemical interpretation, which gave rise to a major revision of the original 864 model, and significantly improved our understanding of the regional aquifer 865 dynamics.

$866]$

867 Acknowledgements

868 [This study was supported by the regional groundwater resources assessment program 869 (Programme d'acquisition de connaissances sur les eaux souterraines, PACES) of the 
870 Quebec Environment Ministry (Ministère $d u$ Développement durable, de 871 l'Environnement et de la Lutte contre les Changements climatiques, MDDELCC) as well 872 as the Groundwater Mapping Program of the Geological Survey of Canada. Numerous 873 regional partners also supported the study through in-kind as well as monetary 874 contributions, notably the Conférence régionale des élus (CRÉ) de la Montérégie Est. 875 Authors would also like to acknowledge well owners who allowed the sampling of 876 groundwater. Finally, we want to thank two anonymous reviewers who made 877 constructive comments that helped improve the paper significantly.]

\section{References}

879 [Appelo, C.A.J., Postma, D., 2005. Geochemistry, groundwater and pollution. CRC $880 \quad$ Press, Boca Raton (FL), USA, 649 pp.

881 Beaudry, C., 2013. Hydrogéochimie de l'aquifère rocheux régional en Montérégie est, 882 Québec [In French and English]. M.Sc. thesis, INRS, Centre Eau Terre Environnement, Québec, Canada, 196 pp. http://espace.inrs.ca/1363/ (Accessed March, 2018)

Beaudry, C., Malet, X., Lefebvre, R., Rivard, C., 2011. Délimitation des eaux souterraines saumâtres en Montérégie Est, Québec, Canada [In French]. Geological Survey of Canada, Open File Report 6970, August 2011, 26 pp., doi: 10.4095/289123.

Blanchette, D., Lefebvre, R., Nastev, M., Cloutier, V., 2010. Groundwater quality, geochemical processes and groundwater evolution in the Chateauguay River watershed, Quebec, Canada. Canadian Water Resources Journal, 35(4), 503-526, doi: 10.4296/cwrj3504503.

895 Carrier, M.-A., Lefebvre, R., Rivard, C., Parent, M., Ballard, J.-M., Benoit, N., 896 Vigneault, H., Beaudry, C., Malet, X., Laurencelle, M., Gosselin, J.-S., Ladevèze, 

P., Thériault, R., Beaudin, I., Michaud, A., Pugin, A., Morin, R., Crow, H., Gloaguen, E., Bleser, J., Martin, A., Lavoie, D., 2013. Portrait des ressources en eau souterraine en Montérégie Est, Québec, Canada [In French]. INRS Report INRS R-1433, June 2013, 318 pp., ISBN: 978-2-89146-764-3. http://espace.inrs.ca/1639/ (Accessed March, 2018)

902 Clark, T.H., Globensky, Y., Hofmann, H., 1979. Stratigraphie Paléozoïque des Basses903 terres du Saint-Laurent du Québec [In French]. Geological Association of Canada, 904 Field Trip Guidebook, Edited by Université Laval, Ste-Foy, Québec.

905 Clark, I., 2015. Groundwater Geochemistry and Isotopes. CRC Press, Taylor \& Francis 906 Group, Boca Raton, FL, USA, 438 pp.

907 Clark, I.D., Fritz, P., 1997. Environmental Isotopes in Hydrogeology. CRC Press, Boca 908 Raton, FL, USA, 328 pp.

909 Cloutier, V., Lefebvre, R., Savard, M., Bourque, É., Therrien, R., 2006. 910 Hydrogeochemistry and groundwater origin of the Basses-Laurentides sedimentary 911 rock aquifer system, St. Lawrence Lowlands, Québec, Canada. Hydrogeology 912 Journal, 14 (4), 573-590.

913 Cloutier, V., Lefebvre, R., Therrien, R., Savard, M., 2008. Multivariate statistical analysis 914 of geochemical data as indicative of the hydrogeochemical evolution of 915 groundwater in a sedimentary rock aquifer system. Journal of Hydrology, 353 (3916 4), 294-313.

917 Cloutier, V., Lefebvre, R., Savard, M.M., Therrien, R., 2010. Desalination of a 918 sedimentary rock aquifer system invaded by Pleistocene Champlain Sea water and 919 processes controlling groundwater geochemistry. Environmental Earth Sciences, 59(5): $977-994$.

921 Croteau, A., Nastev, M., Lefebvre, R., 2010. Groundwater recharge assessment in the 922 Chateauguay River watershed. Canadian Water Resources Journal, 35(4), 451-468, 923 doi: $10.4296 /$ cwrj3504451. 
924 Davis, J.C., 1986. Statistics and Data Analysis in Geology. John Wiley \& Sons Inc., New 925 York.

926 Feininger, T., Goodacre, A.K., 1995. The eight classical Monteregian hills at depth and 927 the mechanism of their intrusion. Canadian Journal of Earth Sciences, 32(9): 1350$928 \quad 1364$.

929 Gaucher, E., 1984. Compilation de la géologie du Quaternaire - Région des Appalaches. 930 Ministère de l'Énergie et des Ressources du Québec, Report DV 84-10, 89 maps $931 \quad$ (scale $1 / 50000)$.

932 Gibbs, R.J., 1970. Mechanisms controlling world water chemistry. Science, 170(3962): 933 1088-1090.

934 Globensky, Y., 1985. Géologie des Basses-terres du Saint-Laurent [In French]. 935 Gouvernement du Québec, Ministère de l'Énergie et des Ressources, Direction 936 générale de l'Exploration géologique et minérale (Ed.), Map no. 1999 of Report 937 MM 85-02.

938 Gouvernement du Québec, 2012. Règlement sur la qualité de l'eau potable c.Q-2, r.40 [In French]. Ministère du Développement durable, de la Faune et des Parcs, (Ed.).

940 Güler, C., Thyne, G., McCray, J., Turner, K., 2002. Evaluation of graphical and 941 multivariate statistical methods for classification of water chemistry data. $942 \quad$ Hydrogeology Journal, 10(4): 455-474.

943 Han, L.F., Plummer, L.N., 2016. A review of single-sample-based models and other 944 approaches for radiocarbon dating of dissolved inorganic carbon in groundwater. 945 Earth-Science Reviews 152 (2016) 119-142, doi: 10.1016/j.earscirev.2015.11.004.

946 Han, L.F., Plummer, L.N., Aggarwal, P., 2012. A graphical method to evaluate 947 predominant geochemical processes occurring in groundwater systems for 948 radiocarbon dating. Chemical Geology 318-319 (2012) 88-112, 949 doi:10.1016/j.chemgeo.2012.05.004. 
950 Hem, J.D., 1985. Study and interpretation of the chemical characteristics of natural water. U.S. Geological Survey, Water Supply Paper 2254, Alexandria, VA, 263 pp.

952 Hounslow, A.W., 1995. Water Quality Data: Analysis and Interpretation. Lewis 953 Publisher, Boca Raton, Florida, USA, 397 pp.

954 Jackson, R.E., Heagle, D.J., 2016. Sampling domestic/farm wells for baseline 955 groundwater quality and fugitive gas. Hydrogeology Journal, 24: 269-72.

956 Janos, D., 2017. Regional groundwater flow dynamics and residence times in Chaudière957 Appalaches, Québec, Canada: insights from numerical simulations. M.Sc. thesis, 958 Laval University, Quebec City, Canada, 103 pp.

959 Laurencelle, 2018. Propriétés hydrauliques et processus d'invasion par la Mer de 960 Champlain du système aquifère rocheux fracturé régional de la Montérégie Est, 961 Québec, Canada. Ph.D. thesis, INRS, Centre Eau Terre Environnement, http://ete.inrs.ca/ete/publications/theses-memoires\#L

963 Laurencelle, M., Lefebvre, R., Rivard, C., Parent, M., Ladevèze, P., Benoit, N., Carrier, 964 M.-A., 2013. Modeling the evolution of the regional fractured-rock aquifer system 965 in the Northern Lake Champlain watershed following last deglaciation. 966 GéoMontréal2013, $66^{\text {th }}$ Canadian Geotechnical Conference and the $11^{\text {th }}$ Joint 967 CGS/IAH-CNC Groundwater Conference, Montreal, Quebec, Canada, Sept. 29 to $968 \quad$ Oct. 3, 2013.

969 Lefebvre, R., Rivard, C., Carrier, M.A., Gloaguen, E., Parent, M., Pugin, A., Pullan, S., 970 Benoit, N., Beaudry, C., Ballard, J.M., Chasseriau, P., Morin, R.H., 2011. 971 Integrated regional characterization of the Montérégie Est aquifer system, Quebec, Canada. Geohydro2011, Joint IAH-CNC, CANQUA and AHQ conference, Quebec

974 McCormack, R., 1980. Étude hydrogéologique du bassin versant de la Richelieu [In 975 French]. Service des eaux souterraines, Direction générale des inventaires et de la 976 recherche, Ministère de l'Environement, Gouvernement du Québec, Québec, 47 pp. 
977 McIntosh, J.C., S.E. Grasby, S.M. Hamilton, et S.G. Osborn, 2014. Origin, distribution 978 and hydrogeochemical controls on methane occurrences in shallow aquifers, southwestern Ontario, Canada. Applied Geochemistry, 50: 37-52.

980

981

982

983

984

985

986

987

988

989

990

991

992

993

994

995

996

997

998

999

1000

1001

1002

1003

Ministère du Développement durable, de l'Environnement et de la Lutte contre les changements climatiques (MDDELCC), 2017. Programme de connaissances sur les eaux souterraines du Québec [In French]. Web site, http://www.mddelcc.gouv.qc.ca/eau/souterraines/programmes/acquisitionconnaissance.htm (Accessed March, 2018).

Montcoudiol, N., Molson, J., Lemieux, J.M., Cloutier, V., 2015. A conceptual model for groundwater flow and geochemical evolution in the southern Outaouais Region, Québec, Canada. Applied Geochemistry, 58, 62-77, doi: 10.1016/j.apgeochem.2015.03.007.

Occhietti, S., Richard, P.J., 2003. Effet réservoir sur les âges ${ }^{14} \mathrm{C}$ de la Mer de Champlain à la transition Pléistocène-Holocène : révision de la chronologie de la déglaciation au Québec méridional. Géographie physique et Quaternaire, 57 (2-3), 115-138.

Paradis, D., Tremblay, L., Lefebvre, R., Gloaguen, E., Rivera, A., Parent, M., Ballard, J.M., Michaud, Y., Brunet, P., 2014. Field characterization and data integration to define the hydraulic heterogeneity of a shallow granular aquifer at a sub-watershed scale. Environmental Earth Sciences, 72 (5), 1325-1348.

Palmer, S., Campeau, S., Cloutier, V., Daigneault, R., Larocque, M., Lefebvre, R., Lemieux, JM., Molson, J., Rivard, C., Rouleau, A., Therrien, R., 2011. Collaborative approaches to groundwater knowledge acquisition in Quebec: Interregional characterization. Geohydro2011, Joint IAH-CNC, CANQUA and AHQ conference, Quebec City, Canada, August 28-31, 2011, 6 p.

Parent, M., Occhietti, S., 1988. Late Wisconsinan Deglaciation and Champlain Sea Invasion in the St. Lawrence Valley, Québec. Géographie physique et quaternaire, 42(3): 215-246. 
1004 Pétré, M.A., Rivera, A., Lefebvre, R., Hendry, M.J., Folnagy, A.J.B., 2016. A unified

1005

1006

1007

1008

1009

1010

1011

1012

1013

1014

1015

1016

1017

1018

1019

1020

1021

1022

1023

1024

1025

1026

1027

1028

1029 hydrogeological conceptual model of the Milk River transboundary aquifer, traversing Alberta (Canada) and Montana (USA). Online 29 June 2016, Hydrogeology J., 24(7), 1847-1871, doi: 10.1007/s10040-016-1433-8.

Pinti, D.L., Gélinas, Y., Larocque, M., Barnetche, D., Retailleau, S., Moritz, A., Helie, J.F., Lefebvre, R., 2013. Concentrations, sources et mécanismes de migration préférentielle des gaz d'origine naturelle (méthane, hélium, radon) dans les eaux souterraines des Basses-Terres du Saint-Laurent [In French]. Volet géochimie, Étude E3-9, FQRNT ISI n 171083, UQAM, U. Concordia, INRS, Août 2013, 94 p. $\quad$ http://www.bape.gouv.qc.ca/sections/mandats/gaz de_schisteenjeux/documents/PR3.6.9.pdf (Accessed in March, 2018)

Plummer, L.N., Glynn, P.D., 2013. Radiocarbon dating in groundwater systems. Chapter 4, 33-89, In Dating Old Groundwater: A Guidebook, IAEA, Vienna, ISBN 978-920-137210-9.

Prichonnet, G., 1984. Dépôts quaternaires de la région de Granby, Québec [In French]. Commission géologique du Canada (Ed.), Étude 83-30, Ottawa, Canada, 8 pp.

Rey, N., Rosa, E., Cloutier, V., Lefebvre, R., 2017. Using water stable isotopes for tracing surface and groundwater flow systems in the Barlow-Ojibway Clay Belt, Quebec, Canada. Online 11 December 2017, Canadian Water Resources J., 22 pp., doi: 10.1080/07011784.2017.1403960.

Sanford, R.F., Pierson, C.T., Crovelli, R.A., 1993. An objective replacement method for censored geochemical data. Mathematical Geology, 25(1): 59-80.

Schroeder, P.R., Aziz, N.M., Lloyd, C.M., Zappi, P.A., 1994. The hydrologic evaluation of landfill performance (HELP) model: Engineering documentation for version 3. EPA/600/R-94/168b. U.S. Environmental Protection Agency, Office of Research and Development, Washington, D.C., 126 pp. 
1030

1031

1032

1033

1034

1035

1036

1037

1038

1039

1040

1041

1042

1043

1044

Séjourné, S., Lefebvre, R., Malet, X., Lavoie, D., 2013. Synthèse géologique et hydrogéologique du Shale d'Utica et des unités sus-jacentes (Lorraine, Queenston et dépôts meubles), Basses-Terres du Saint-Laurent, Province de Québec. Geological Survey of Canada, Open File 7338, 156 p.

Slivitzky, A., Saint-Julien, P., 1987. Compilation géologique de la région de l'EstrieBeauce [In French]. Ministère de l'Énergie et des Ressources, Report MM 85-04, Québec, Canada, 48 pp., 1 map (1/ 250 000).

StatSoft Inc., 2004. STATISTICA (Data Analysis Software System), Version 6.

Tóth, J., 1963. A theoretical analysis of groundwater flow in small drainage basins. Journal of Geophysical Research, 68(16), 4795-4812, doi: 10.1029/JZ068i016p04795.

Tóth, J., 1999. Groundwater as a geologic agent: An overview of the causes, processes, and manifestations. Hydrogeology Journal, 7(1), 1-14, doi: 10.1007/s100400050176.

Tremblay, L., Lefebvre, R., Paradis, D., Gloaguen, E., 2014. Conceptual model of leachate migration in a granular aquifer derived from the integration of multisource characterization data (St-Lambert, Canada). Hydrogeology J., 22(3), 587608 .

Valder, J.F., Long, A.J., Davis, A.D., Kenner, S.J., 2012. Multivariate statistical approach to estimate mixing proportions for unknown end members. Journal of Hydrology, 460-461: 65-76.

Vautour, G., Pinti, D.L., Méjean, P., Saby, M., Meyzonnat, G., Larocque, M., Castro, M.C., Hall, C.M., Boucher, C., Roulleau, E., Barbecot, F., Takahata, N., Sanoc, Y., 2015. ${ }^{3} \mathrm{H} /{ }^{3} \mathrm{He},{ }^{14} \mathrm{C}$ and $(\mathrm{U}-\mathrm{Th}) / \mathrm{He}$ groundwater ages in the St. Lawrence Lowlands, Quebec, Eastern Canada. Chemical Geology 413 (2015) 94-106. 
1056 


\section{Figure Captions}

1058

1059 Figure 1. Montérégie Est location and hydrogeological contexts based on physiography.

1060 Map also shows topography, main roads, the Champlain Sea maximum marine 1061 transgression limit $(\sim 11000$ years ago $)$ and the trace of the cross-sections shown on the 1062 3D block diagram of Figure 2 (dashed red lines).

1063

1064 Figure 2. 3D block diagram of subsurface conditions in Montérégie Est (cross-sections

1065 locations shown on Figure 1). The generally east-west cross-section goes from the 1066 Lowlands to the Appalachian Uplands and crosses the thrust faults of the Appalachian 1067 Front. The generally north-south cross-section remains in the Lowlands but crosses a 1068 Monteregian Hill. Till (green) covers most of the bedrock, with local accumulations of 1069 fluvio-glacial sediments (orange) or old sediments (brown), and is apparent at surface in 1070 the Appalachian Piedmont and Uplands. Lacustrine (purple) and marine (light blue) fine 1071 sediments can form large accumulations in the North Lowlands (more than $30 \mathrm{~m}$ thick).

1073 Figure 3. Confinement level of the Montérégie Est fractured rock aquifer system and 1074 extent of brackish groundwater, to the north of the region.

1076 Figure 4. Results of multivariate statistical analysis of geochemical parameters. A) 1077 Cluster Analysis tree diagram defining the 8 water groups below a phenon line of 18. B) 1078 Spatial distribution of the 190 samples with colored areas belonging to a water group. C) 1079 Values of the $1^{\text {st }}$ and $2^{\text {nd }}$ components of the Principal Component Analysis for the 190 1080 samples identified with their water group. The names of water groups were assigned on 1081 the basis of their spatial distribution (Figure 4B) and their geochemical characteristics 1082 (Figure 5): three "Appalachian" groups A1, A2 and A3; a "Lowland" group LL; a 
1083 "Champlain Sea" group CS; and three "Mixed" or "Monteregian" groups M1, M2 and 1084 M3.

1086 Figure 5. Major ions in groundwater. A) Proportions of major ions for each sample, 1087 associated with its water group (color), represented on a Piper diagram. B) Average ionic 1088 composition for each water group represented by Stiff diagrams (ions represented and 1089 concentration scale shown to the left of diagrams). The order of Stiff diagrams is based 1090 on relations between water groups and geochemical evolution paths that will be discussed 1091 later.

1093 Figure 6. Geochemical conditions for the water groups found in Montérégie Est. A 1094 Average pe and $\mathrm{pH}$ values for the eight water groups. B) Champlain Sea water mixing. 1095 C) Carbonate dissolution mechanism indicated by a $\mathrm{Ca} / \mathrm{HCO}_{3}$ ratio (in $\mathrm{mmol} / \mathrm{L}$ ) of $1: 2$ 1096 (dashed line). D) Evidence of groundwater freshening due to Na-Ca ion exchange.

1098 Figure 7. Mixing and relations between water groups and groundwater geochemical end1099 members. A) Samples of water groups defined in Figures 4 and 5 according to the $1^{\text {st }}$ and

$11002^{\text {nd }}$ components of the Principal Component Analysis (PCA). B) Relative concentrations 1101 of major cations (X-axis) and major anions (Y-axis), similar to a Piper plot, supporting 1102 relations shown on the PCA graph. Inferred geochemical end-members are superposed on 1103 both graphs: Sea Water, Lowland Recharge, Monteregian Water and Appalachian 1104 Recharge.

1106 Figure 8. Isotopic composition of groundwater. A) Stable isotopes of groundwater by 1107 groups compared to the Basses-Laurentides meteoric water line (BLMWL; Cloutier et al. 1108 2006). B) Residence time of water groups indicated by tritium $\left({ }^{3} \mathrm{H}\right.$ is in tritium units, TU) 1109 and radiocarbon (non-corrected ${ }^{14} \mathrm{C}$ ages in years before present, BP). Samples analyzed 
1110 for only one of the two parameters are still represented in the left and bottom margins of 1111 the graph. Ellipses indicate the distribution of samples for water groups.

1113 Figure 9. Geochemical evolution paths and residence time. A) $\mathrm{Na} / \mathrm{Ca}$ ratio versus 1114 uncorrected ${ }^{14} \mathrm{C}$ ages. B) Corrected ${ }^{14} \mathrm{C}$ age range of water groups (Table 3). Sample 1115 colors are related to water groups as defined in Figures 4A and 5.

1116

1117 Figure 10. Conceptual model of groundwater geochemical evolution in Montérégie Est. 1118 Each of the 8 water groups is represented with the direction of evolution (arrows) and the 1119 main mechanisms involved (mixing, geological influence, ion exchange) and the 1120 corrected radiocarbon age range (see Table 3).

1122 Figure 11. Geochemical conceptual model represented by a schematic cross-section from 1123 the Appalachian Uplands to the St. Lawrence River. Water group locations are illustrated 1124 with associated colors and flow directions are represented by arrows. The limit of the 1125 former Champlain Sea is indicated by dashed lines on the map and section. 
2 Table 1. Loadings of the 16 geochemical parameters for the first 5 components (C1 3 through C5) of the Principal Component Analysis (bold values indicate dominant 4 parameters).

\begin{tabular}{cccccc}
\hline Parameters & $\mathbf{C 1}$ & $\mathbf{C 2}$ & $\mathbf{C 3}$ & $\mathbf{C 4}$ & $\mathbf{C 5}$ \\
\hline $\mathbf{p H}$ & -0.384 & 0.535 & 0.117 & $\mathbf{0 . 5 9 4}$ & -0.054 \\
$\mathbf{p e}$ & 0.549 & 0.044 & -0.381 & $-\mathbf{0 . 4 7 5}$ & -0.156 \\
$\mathbf{T D S}$ & $\mathbf{- 0 . 8 9 9}$ & 0.065 & -0.332 & -0.075 & 0.110 \\
$\mathbf{H C O}_{3}$ & $\mathbf{- 0 . 8 3 4}$ & 0.181 & -0.015 & -0.164 & 0.172 \\
$\mathbf{N H}_{\mathbf{4}}$ & $\mathbf{- 0 . 8 3 1}$ & 0.145 & 0.191 & -0.069 & -0.019 \\
$\mathbf{B a}$ & -0.693 & -0.100 & $\mathbf{0 . 4 8 9}$ & -0.141 & -0.199 \\
$\mathbf{B}$ & $\mathbf{- 0 . 8 0 8}$ & 0.439 & -0.052 & -0.020 & -0.099 \\
$\mathbf{C a}$ & -0.162 & $-\mathbf{0 . 9 3 7}$ & -0.058 & -0.063 & -0.164 \\
$\mathbf{C l}$ & -0.733 & 0.017 & -0.393 & -0.167 & 0.141 \\
$\mathbf{M g}$ & -0.422 & $-\mathbf{0 . 8 0 2}$ & 0.043 & -0.015 & -0.221 \\
$\mathbf{M n}$ & -0.286 & -0.629 & 0.123 & 0.250 & 0.221 \\
$\mathbf{K}$ & -0.793 & -0.059 & -0.006 & -0.224 & -0.093 \\
$\mathbf{S i}$ & -0.182 & -0.525 & 0.290 & -0.135 & $\mathbf{0 . 6 6 5}$ \\
$\mathbf{N a}$ & $\mathbf{- 0 . 8 0 3}$ & 0.4223 & -0.268 & 0.083 & 0.061 \\
$\mathbf{S r}$ & -0.603 & -0.570 & 0.002 & 0.158 & -0.356 \\
$\mathbf{S O}$ & 0.0164 & -0.545 & $-\mathbf{0 . 6 4 8}$ & 0.365 & 0.103 \\
\hline \% total & $\mathbf{3 9 . 2}$ & $\mathbf{2 2 . 2}$ & 8.1 & 6.0 & 5.3 \\
variance & & & & &
\end{tabular}


Table 2. Median values of physico-chemical parameters and component and water group statistics are available in Beaudry 2013).

\begin{tabular}{|c|c|c|c|c|c|c|c|c|c|}
\hline Category & Parameter & $\begin{array}{l}C S \\
N=3\end{array}$ & $\begin{array}{c}M 3 \\
N=19\end{array}$ & $\begin{array}{c}M 1 \\
N=19\end{array}$ & $\begin{array}{c}M 2 \\
N=14\end{array}$ & $\begin{array}{c}\text { LL } \\
N=46\end{array}$ & $\begin{array}{c}A 2 \\
N=26\end{array}$ & $\begin{array}{c}\text { A3 } \\
N=41\end{array}$ & $\begin{array}{c}\text { A1 } \\
\mathrm{N}=22\end{array}$ \\
\hline \multirow{4}{*}{$\begin{array}{l}\text { Physico- } \\
\text { chemical }\end{array}$} & $\mathrm{pH}$ & 7.59 & 8.26 & 8.69 & 7.805 & 7.235 & 7.855 & 7.83 & $\underline{6.405}$ \\
\hline & TDS & 2961 & 1340 & 723 & 517 & 673 & 321 & 283 & $\underline{168}$ \\
\hline & D.O. & $\underline{0.17}$ & 0.34 & 0.32 & 0.49 & 0.37 & 0.525 & 0.38 & 5.745 \\
\hline & pe & $\underline{-0.41}$ & 3.15 & 2.35 & 2.09 & 3.29 & 5.39 & 3.55 & 6.49 \\
\hline \multirow{6}{*}{$\begin{array}{l}\text { Major } \\
\text { ions }\end{array}$} & $\mathrm{Na}$ & 630 & 380 & 190 & 74 & 34 & 60.5 & 9.7 & $\underline{4}$ \\
\hline & $\mathrm{Ca}$ & 310 & 9.2 & $\underline{3.8}$ & 30 & 85.5 & 12.5 & 35 & 28 \\
\hline & Mg & 110 & 11 & $\underline{1.5}$ & 17.5 & 28 & 4.45 & 11 & 4.25 \\
\hline & $\mathrm{Cl}$ & 340 & 260 & 39 & 25.5 & 38 & 14 & 7.9 & $\underline{6.3}$ \\
\hline & $\mathrm{SO}_{4}$ & 1500 & $\underline{0.5}$ & 13 & 2.2 & 66.5 & 27.5 & 18 & 13 \\
\hline & $\mathrm{HCO}_{3}$ & 158.0 & 642.1 & 351.5 & 355.6 & 329.0 & 180.4 & 158.4 & $\underline{89.0}$ \\
\hline \multirow{7}{*}{$\begin{array}{l}\text { Minor } \\
\text { ions }\end{array}$} & $\mathrm{K}$ & 23 & 5.6 & 1.7 & 4.95 & 3.05 & 0.835 & 0.8 & $\underline{0.74}$ \\
\hline & $\mathrm{Sr}$ & 9.1 & 0.83 & $\underline{0.19}$ & 2.85 & 1.85 & 0.905 & 0.6 & 0.2 \\
\hline & $\mathrm{Fe}$ & 1.2 & 0.14 & $\underline{0.015}$ & 0.17 & 0.36 & 0.024 & 0.11 & $\underline{0.015}$ \\
\hline & $F$ & 0.5 & 1.2 & 1 & 0.5 & 0.1 & 0.45 & 0.1 & $\underline{0.05}$ \\
\hline & $\mathrm{CO}_{3}$ & 0.219 & 2.665 & 6.821 & 0.716 & 0.190 & 0.576 & 0.266 & $\underline{0.009}$ \\
\hline & $\mathrm{N}-\mathrm{NO}_{3}$ & 0.01 & 0.01 & 0.01 & 0.01 & 0.01 & 0.01 & 0.01 & 0.43 \\
\hline & $\mathrm{NH}_{4}$ & 2.8 & 1.5 & 0.47 & 0.96 & 0.26 & 0.045 & 0.06 & $\underline{0.03}$ \\
\hline \multirow{4}{*}{ Traces } & $\mathrm{Ba}$ & 0.016 & 0.6 & 0.074 & 1.15 & 0.15 & 0.033 & 0.074 & $\underline{0.0115}$ \\
\hline & B & 1.2 & 0.51 & 0.36 & 0.225 & 0.0505 & 0.038 & 0.009 & $\underline{0.0025}$ \\
\hline & $\mathrm{Br}$ & 0.5 & 0.5 & 0.05 & 0.05 & 0.05 & 0.05 & 0.05 & 0.05 \\
\hline & Mn & 0.36 & 0.011 & 0.0055 & 0.023 & 0.0785 & 0.0265 & 0.071 & $\underline{0.00225}$ \\
\hline
\end{tabular}


2 Table 3. Ranges of tritium $\left({ }^{3} \mathrm{H}\right)$, uncorrected (lab.) and corrected ${ }^{14} \mathrm{C}$ ages for the water groups.

\begin{tabular}{ccccccc}
\hline $\begin{array}{c}\text { Water } \\
\text { Group }\end{array}$ & $\begin{array}{c}{ }^{3} \mathbf{H} \text { range } \\
\text { (TU) }\end{array}$ & $\begin{array}{c}{ }^{14} \mathbf{C} \text { values } \\
\text { (Analyses) }\end{array}$ & $\begin{array}{c}\text { Range of } \\
\text { Lab. Age } \\
\text { (ky BP) }\end{array}$ & $\begin{array}{c}\text { Rounded } \\
\text { Min. Age } \\
\text { (ky BP) }\end{array}$ & $\begin{array}{c}\text { Middle of } \\
\text { Range } \\
\text { (ky BP) }\end{array}$ & $\begin{array}{c}\text { Rounded } \\
\text { Max. Age } \\
\text { (ky BP) }\end{array}$ \\
\hline CS & $6.6(1)$ & $2(3)$ & $14.2-14.8$ & 13.9 & 13.9 & 13.9 \\
M3 & $0.0(3)$ & $4(4)$ & $3.8-16.6$ & 3.6 & 8.8 & 14.0 \\
M1 & $3.2-4.9(3)$ & $4(4)$ & $7.2-12.5$ & 4.3 & 5.5 & 6.7 \\
M2 & $1.0-9.6(3)$ & $3(5)$ & $2.3-6.1$ & Modern & 1.95 & 3.9 \\
LL & $10.4-12.6(6)$ & $2(4)$ & $0.06-5.2$ & Modern & 0.75 & 1.5 \\
A2 & $0.4-4.2(8)$ & $7(7)$ & $6.2-16.0$ & 3.0 & 7.5 & 12.0 \\
A3 & $6.3-9.7(11)$ & $6(7)$ & $3.3-11.8$ & 3.0 & 6.0 & 9.0 \\
A1 & $13.2-14.5(4)$ & $0(4)$ & $0.0-3.2$ & Modern & Modern & Modern \\
\hline 1: 25 $5^{\text {tn }}$ to $75^{\text {ln }}$ percentiles of the number of analyses in bracket. 2: The number of \\
quantitatively interpreted ${ }^{14} \mathrm{C}$ age values among the number of available analyses. \\
Analyses that could not be interpreted were either modern groundwater or had a \\
log $\left(\mathrm{pCO}_{2}\right.$ ) value exceeding -2.0 indicative of an open $\mathrm{CO}_{2}$ system (Clark 2015).
\end{tabular}




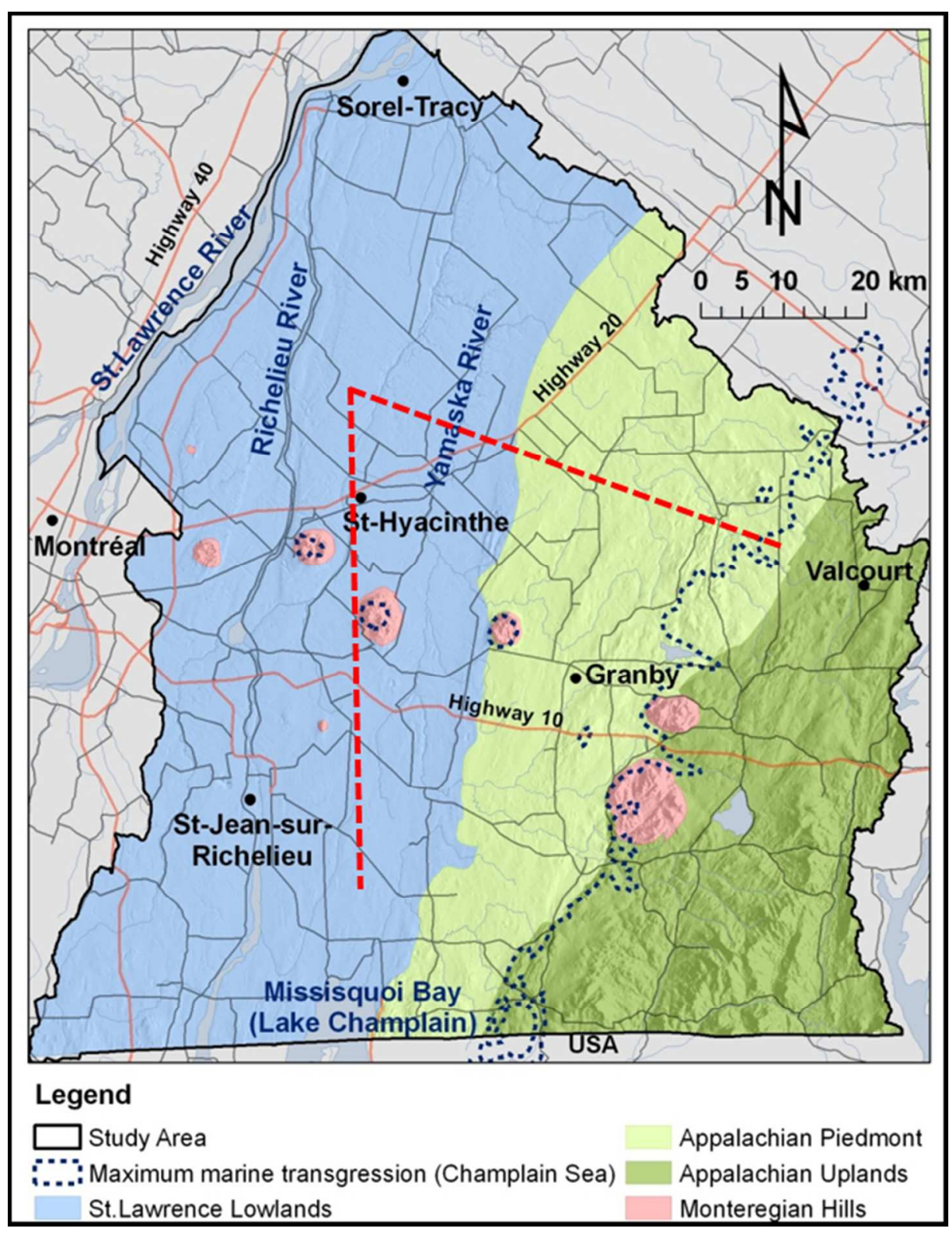

Figure 1. Montérégie Est location and hydrogeological contexts based on physiography. Map also shows topography, main roads, the Champlain Sea maximum marine transgression limit ( $\sim 11000$ years ago) and the trace of the cross-sections shown on the 3D block diagram of Figure 2 (dashed red lines). 


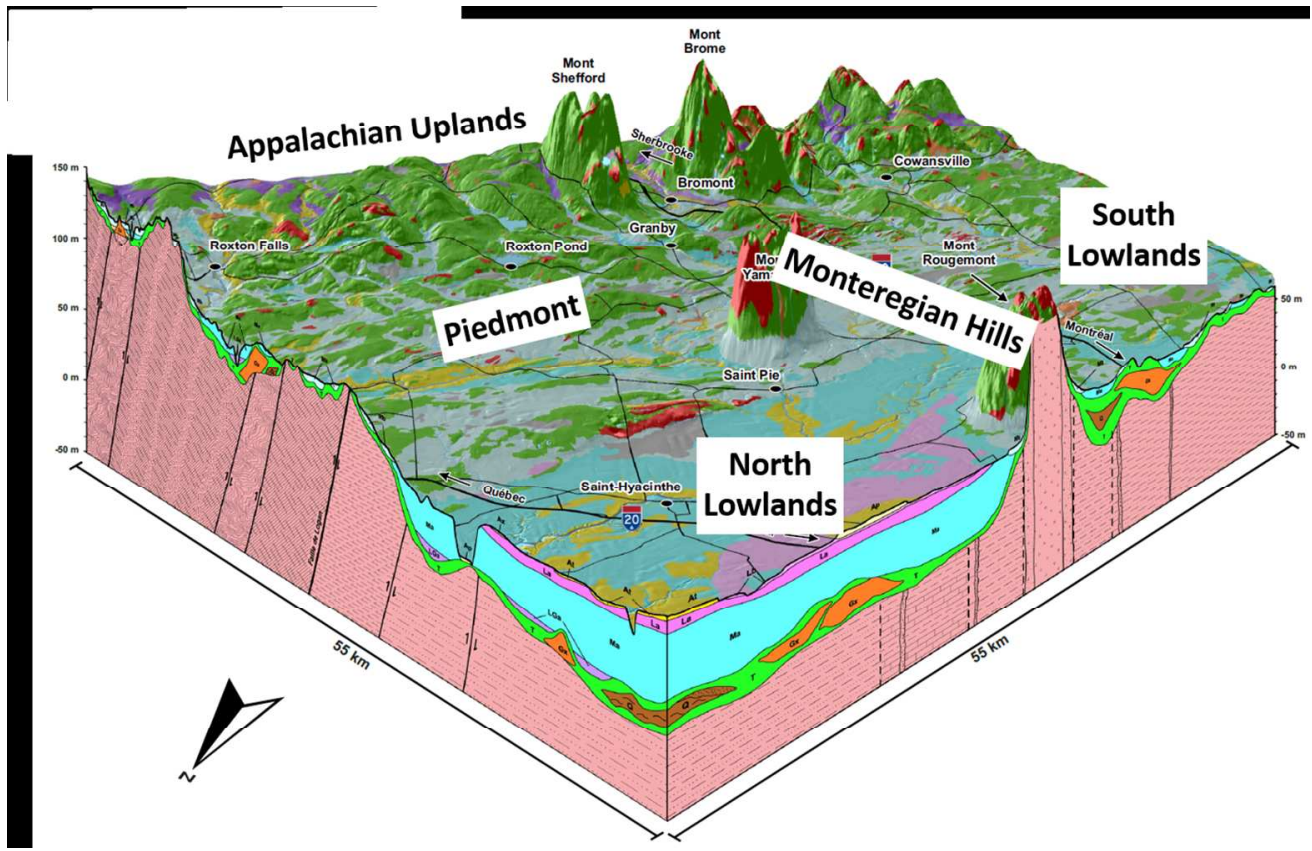

Figure 2. 3D block diagram of subsurface conditions in Montérégie Est (cross-sections locations shown on Figure 1). The generally east-west cross-section goes from the Lowlands to the Appalachian Uplands and crosses the thrust faults of the Appalachian Front. The generally north-south cross-section remains in the Lowlands but crosses a Monteregian Hill. Till (green) covers most of the bedrock, with local accumulations of fluvio-glacial sediments (orange) or old sediments (brown), and is apparent at surface in the Appalachian Piedmont and Uplands. Lacustrine (purple) and marine (light blue) fine sediments can form large accumulations in the North Lowlands (more than $30 \mathrm{~m}$ thick).

$240 \times 155 \mathrm{~mm}(150 \times 150 \mathrm{DPI})$ 


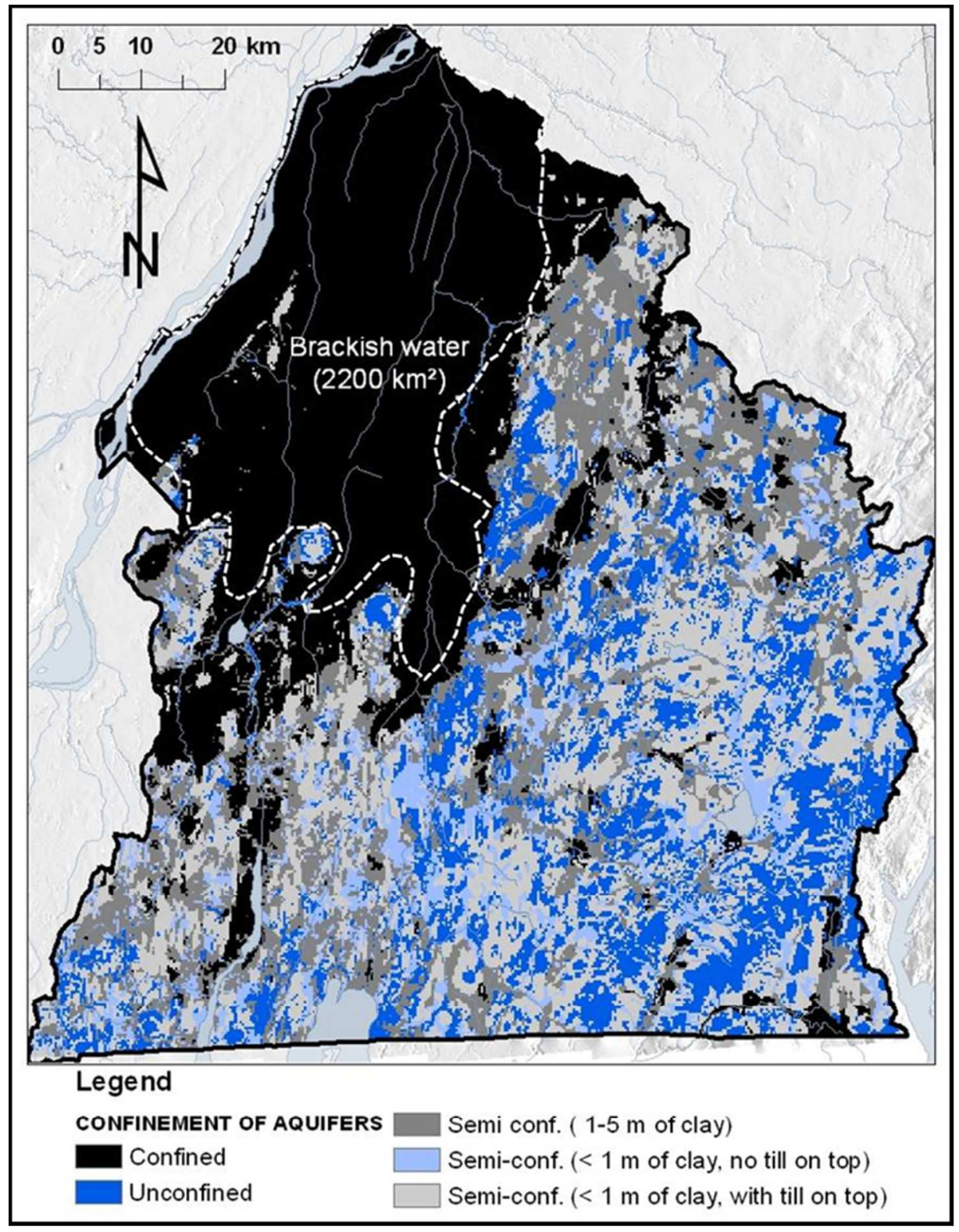

Figure 3. Confinement level of the Montérégie Est fractured rock aquifer system and extent of brackish groundwater, to the north of the region.

$126 \times 163 \mathrm{~mm}(150 \times 150 \mathrm{DPI})$ 
A)

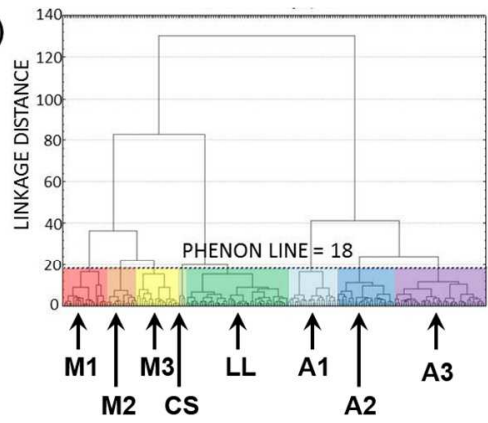

C)

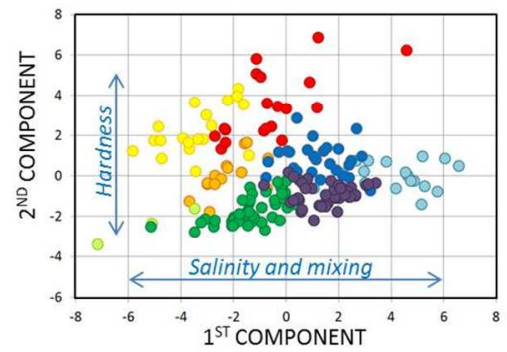

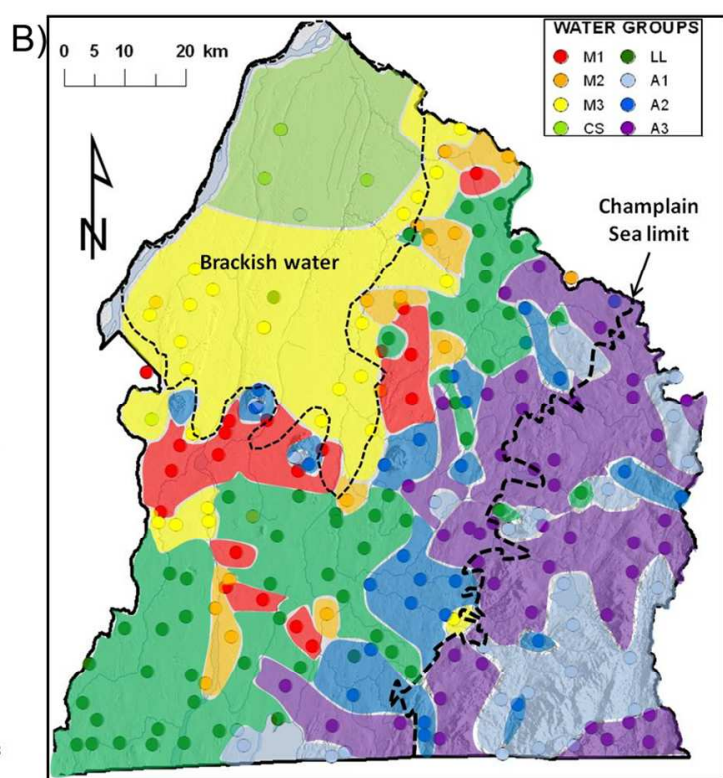

Figure 4. Results of multivariate statistical analysis of geochemical parameters. A) Cluster Analysis tree diagram defining the 8 water groups below a phenon line of 18. B) Spatial distribution of the 190 samples with colored areas belonging to a water group. C) Values of the 1st and 2nd components of the Principal Component Analysis for the 190 samples identified with their water group. The names of water groups were assigned on the basis of their spatial distribution (Figure 4B) and their geochemical characteristics (Figure 5): three "Appalachian" groups A1, A2 and A3; a "Lowland" group LL; a "Champlain Sea" group CS; and three "Mixed" or "Monteregian" groups M1, M2 and M3.

$251 \times 154 \mathrm{~mm}(150 \times 150 \mathrm{DPI})$ 
A) Piper Diagram

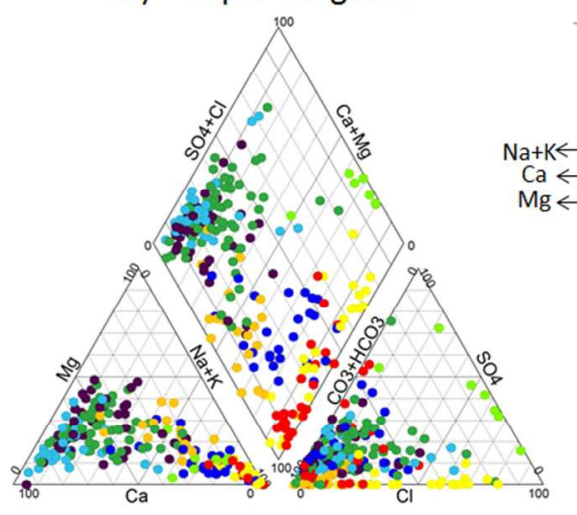

B) Stiff Diagrams

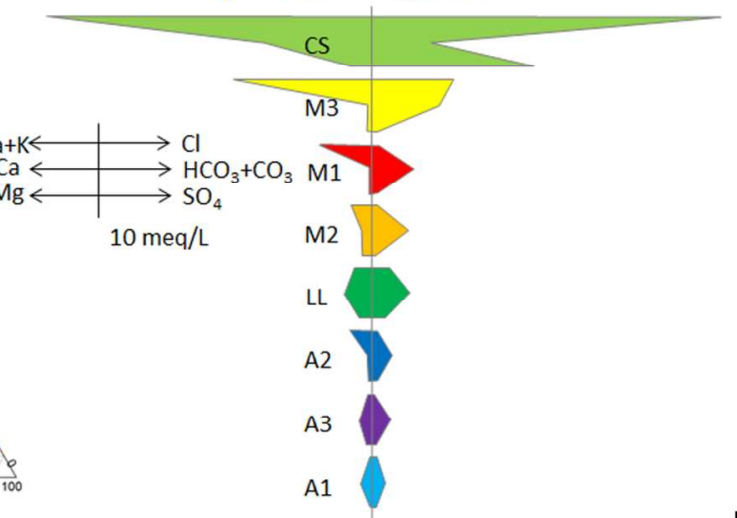

Figure 5. Major ions in groundwater. A) Proportions of major ions for each sample, associated with its water group (color), represented on a Piper diagram. B) Average ionic composition for each water group represented by Stiff diagrams (ions represented and concentration scale shown to the left of diagrams). The order of Stiff diagrams is based on relations between water groups and geochemical evolution paths that will be discussed later.

$222 \times 100 \mathrm{~mm}(150 \times 150 \mathrm{DPI})$ 

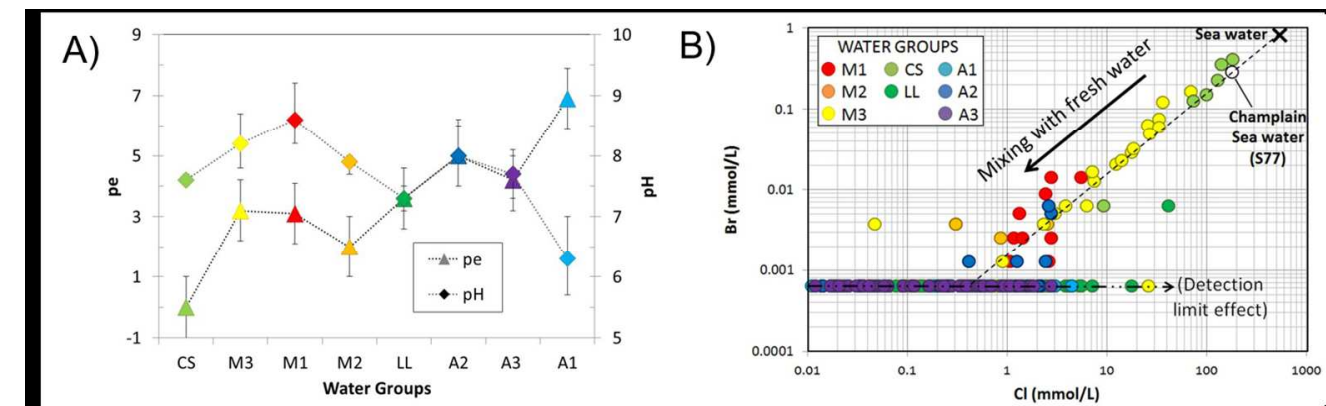

C)

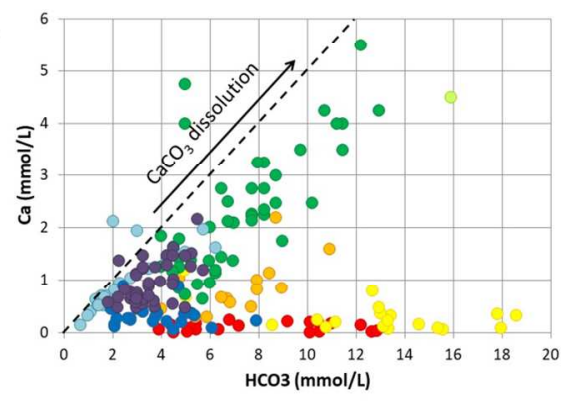

D)

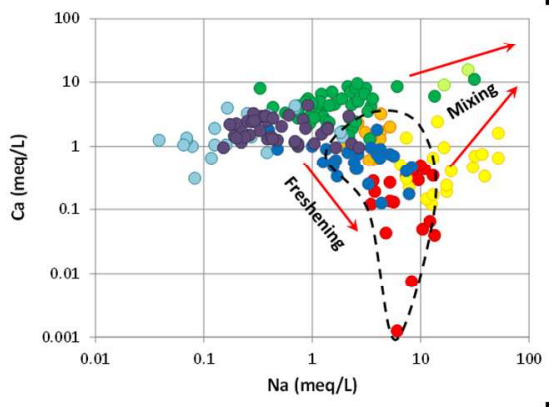

Figure 6. Geochemical conditions for the water groups found in Montérégie Est. A Average pe and pH values for the eight water groups. B) Champlain Sea water mixing. C) Carbonate dissolution mechanism indicated by a $\mathrm{Ca} / \mathrm{HCO}_{3}$ ratio (in $\mathrm{mmol} / \mathrm{L}$ ) of $1: 2$ (dashed line). D) Evidence of groundwater freshening due to $\mathrm{Na}-\mathrm{Ca}$ ion exchange.

$247 \times 160 \mathrm{~mm}(150 \times 150 \mathrm{DPI})$ 


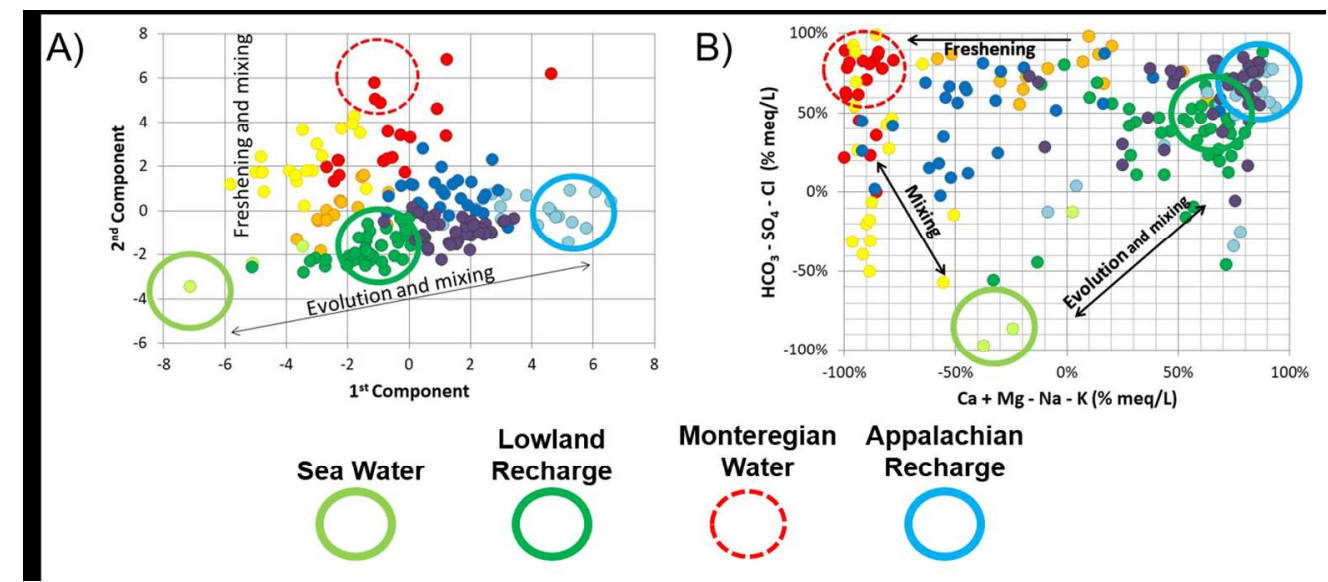

Figure 7. Mixing and relations between water groups and groundwater geochemical end-members. A) Samples of water groups defined in Figures 4 and 5 according to the 1 st and 2nd components of the Principal Component Analysis (PCA). B) Relative concentrations of major cations (X-axis) and major anions (Y-axis), similar to a Piper plot, supporting relations shown on the PCA graph. Inferred geochemical endmembers are superposed on both graphs: Sea Water, Lowland Recharge, Monteregian Water and Appalachian Recharge.

$240 \times 105 \mathrm{~mm}(150 \times 150$ DPI $)$ 

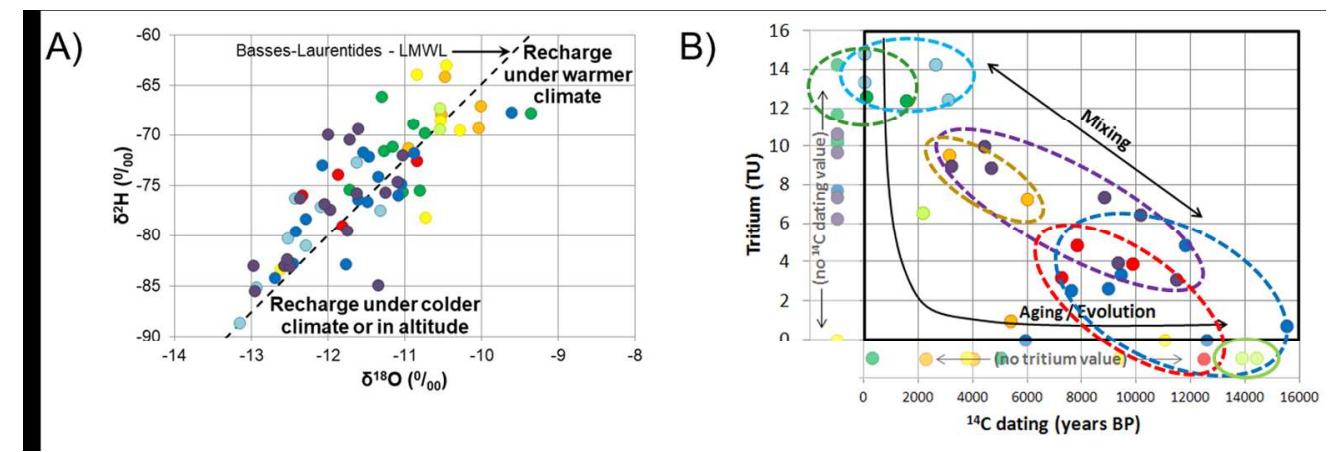

Figure 8. Isotopic composition of groundwater. A) Stable isotopes of groundwater by groups compared to the Basses-Laurentides meteoric water line (BLMWL; Cloutier et al. 2006). B) Residence time of water groups indicated by tritium ( $3 \mathrm{H}$ is in tritium units, TU) and radiocarbon (non-corrected $14 \mathrm{C}$ ages in years before present, BP). Samples analyzed for only one of the two parameters are still represented in the left and bottom margins of the graph. Ellipses indicate the distribution of samples for water groups.

$$
246 \times 83 \mathrm{~mm}(150 \times 150 \mathrm{DPI})
$$



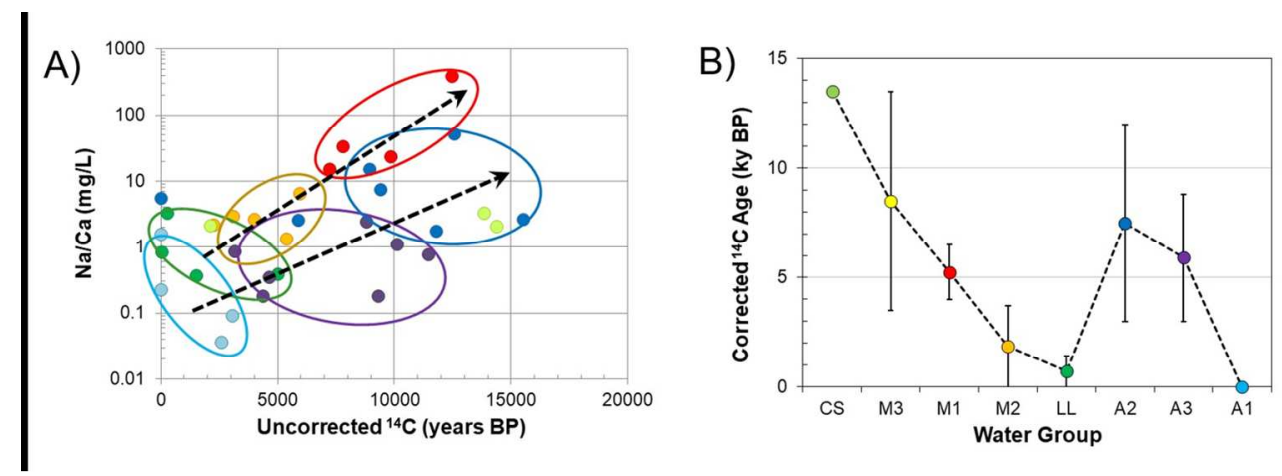

Figure 9. Geochemical evolution paths and residence time. A) Na/Ca ratio versus uncorrected $14 \mathrm{C}$ ages. B) Corrected $14 \mathrm{C}$ age range of water groups (Table 3 ). Sample colors are related to water groups as defined in Figures $4 \mathrm{~A}$ and 5.

$245 \times 86 \mathrm{~mm}(150 \times 150 \mathrm{DPI})$ 


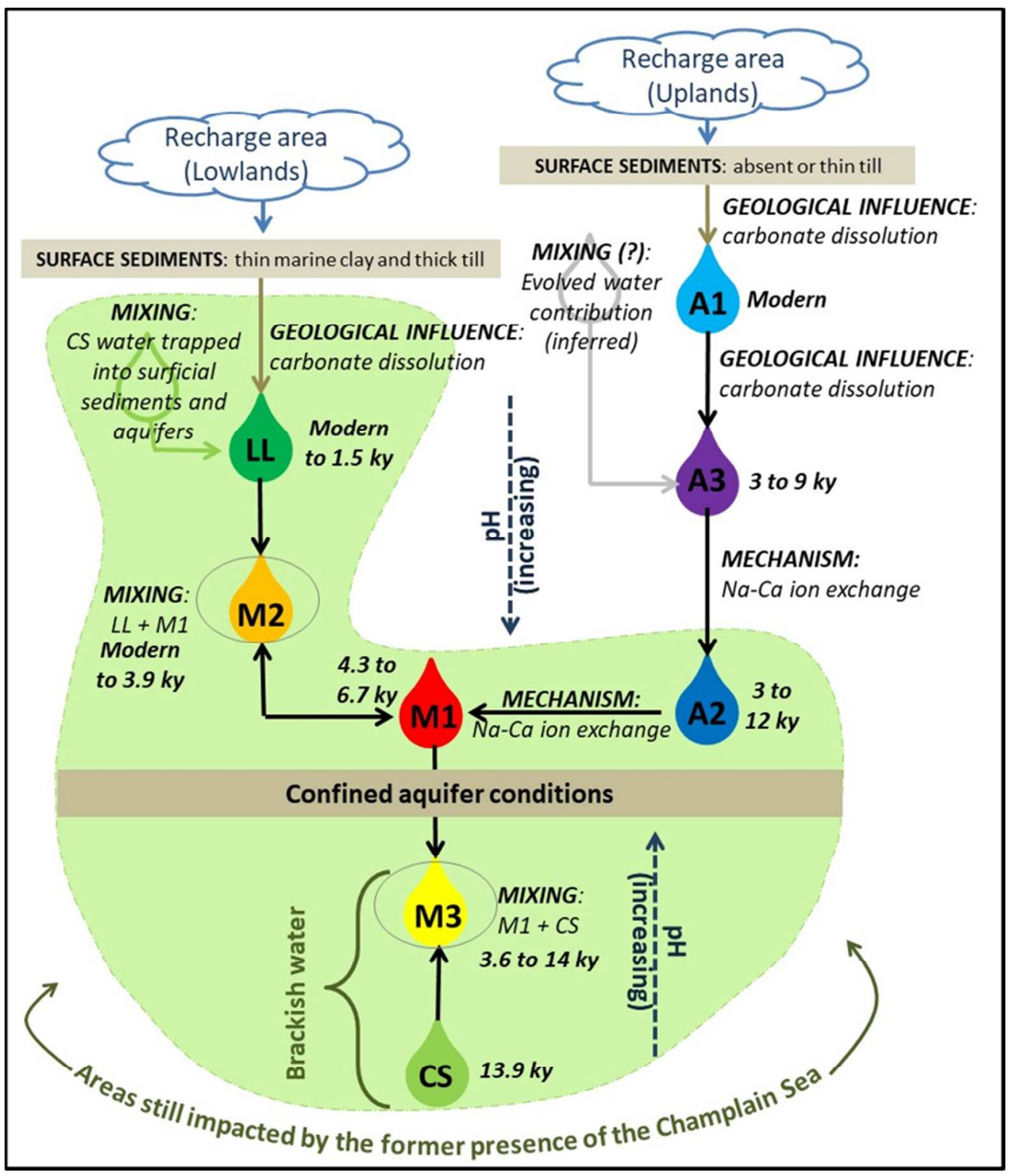

Figure 10. Conceptual model of groundwater geochemical evolution in Montérégie Est. Each of the 8 water groups is represented with the direction of evolution (arrows) and the main mechanisms involved (mixing, geological influence, ion exchange) and the corrected radiocarbon age range (see Table 3 ).

$$
143 \times 167 \mathrm{~mm}(150 \times 150 \mathrm{DPI})
$$




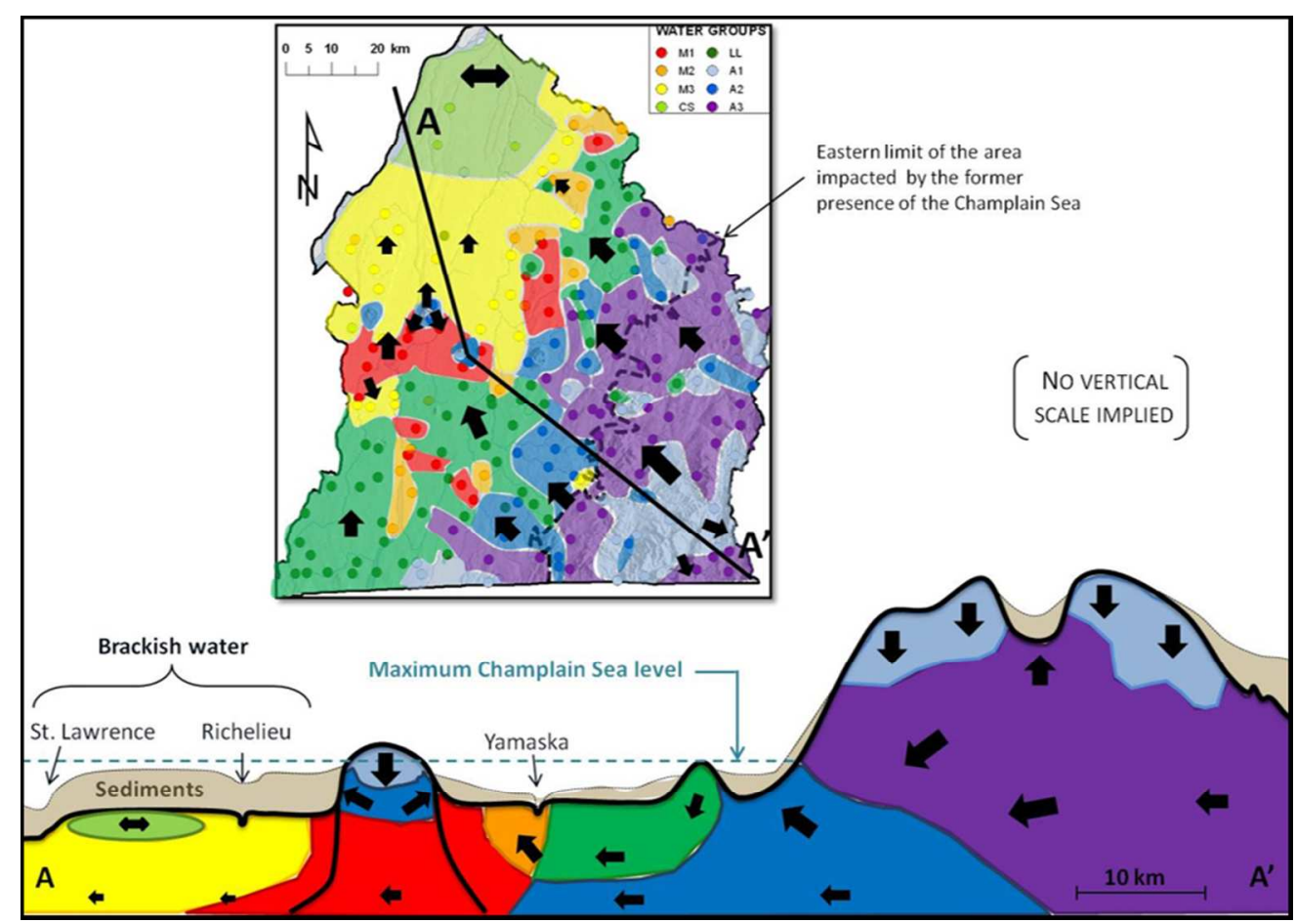

Figure 11. Geochemical conceptual model represented by a schematic cross-section from the Appalachian Uplands to the St. Lawrence River. Water group locations are illustrated with associated colors and flow directions are represented by arrows. The limit of the former Champlain Sea is indicated by dashed lines on the map and section.

$166 \times 118 \mathrm{~mm}(150 \times 150 \mathrm{DPI})$ 